ASSESSMENT OF STORM DRAIN SOURCES OF CONTAMINANTS TO SANTA MONICA BAY

\author{
VOLUME IV \\ SELECTION OF BEST MANAGEMENT PRACTICES \\ FOR CONTROL OF STORM WATER POLLUTION TO \\ SANTA MONICA BAY
}

\author{
Michael K. Stenstrom \\ Department of Civil and Environmental Engineering \\ University of California, Los Angeles \\ and \\ Eric W. Strecker \\ Woodward-Clyde Consultants \\ Principal Investigators
}

\author{
Contributors \\ Lou Armstrong \\ Gail Boyd \\ Sim-Lin Lau
}

May 281993

SCHOOL OF ENGINEERING AND APPLIED SCIENCE

Report No. ENGR 93-65 
This report represents Volume IV from a series of four volumes of reports which form the basis of a pollution assessment and monitoring plan for Santa Monica Bay. Volume I describes land use statistics, catchment areas, existing water quality monitoring data, rainfall data, NPDES permit information for existing permits to storm drains, and contaminant mass emission estimates, based upon land use modeling. Volume II reviews sampling techniques, including sampling equipment, and other aspects associated with sampling such as a quality assurance plan. Volume III presents the proposed monitoring plan. Volume IV addresses best management practices as they apply to the Santa Monica Bay area. The first draft of Volume IV was issued on November 9, 1992.

The contract was performed by UCLA and Woodward-Clyde Consultants (WCC). Professor Michael K. Stenstrom of the Civil and Environmental Engineering Department, UCLA and Eric Strecker from WCC's Portland office were the project managers. There were several key individuals from both UCLA and WCC who assisted with the project; they include Sim-Lin Lau and Kenneth Wong (UCLA) and Lou Armstrong, Gail Boyd, Carol Forrest, and Joan Kersnar (WCC).

The contractors are grateful for the assistance of many individuals. The Santa Monica Bay Project and LA Regional Water Quality Control Board staffs were most helpful. We extend our special thanks to Dr. Guang-yu Wang, Ms. Catherine Tyrrell, Dr. Rainer Hoeinke and Mr. Xavier Swamikannu. Several public agencies were very helpful in providing data and information to us. The Los Angeles County Department of Public Works and the Southern California Association of Governments (SCAG) provided catchment area and land use data, respectively. We are also indebted to the members of the Technical Advisory Committee of the Santa Monica Bay Project and others who reviewed and commented on our draft reports. 
This report presents a procedure for developing a suite of best management practices (BMPs) to control or reduce pollutants from nonpoint sourcs to Santa Monica Bay. Provisions are made for stormwater as well as dry weather flow. The procedure provide a methodology for operators of municipal storm water drainage system in Santa Monica Bay to select appropriate BMPs based upon available knowledge and resources. The procedure includes a "menu" concept where three menus of BMPs are provided. The first menu (Menu A) represents very important BMPs which might be considered mandatory. Menus B and C list BMPs that are complementry to Menu A but are more difficult to implement or produce less certain benefits. These BMPs are optinal and a technique is presented for screening the various BMPs in order to identify those most applicable to the Santa Monica Bay watershed.

During the course of this project a variety of BMPs were discussed or researched at various times by contract personnel or by others participating or reviewing the project. In order to perserve this information, the various BMPs are listed in an Appendix. Most of these BMPs are similar to one or more items covered in a menu but are more specific to the Santa Monica Bay watershed. The Appendix provides additional information which should be helpful in deciding to implement or implementing the BMP. 


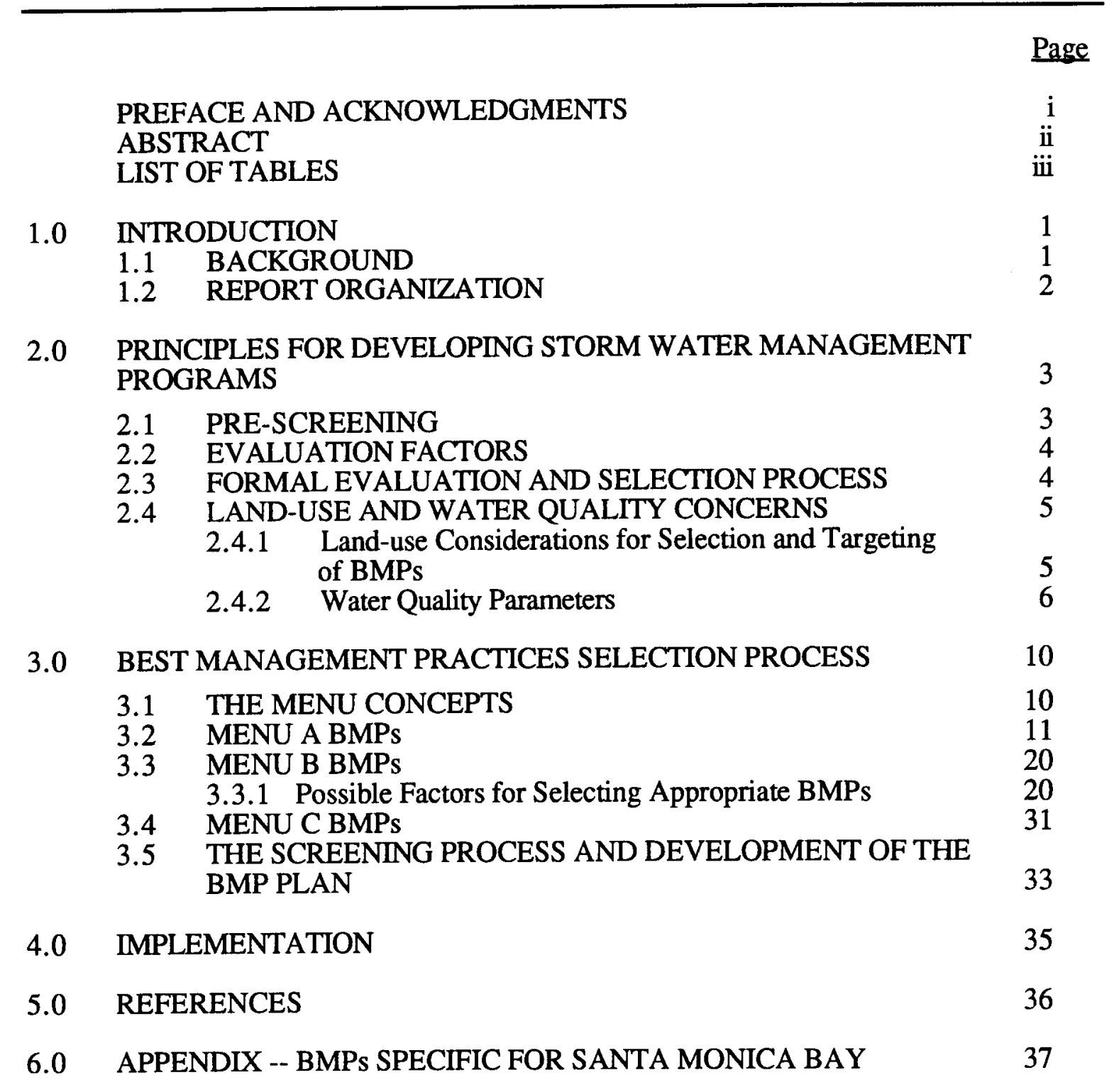


Page

3-1 Best Management Practices for Public Education $\quad 12$

3-2 Best Management Practices for Industrial Facilities 13

3-3 Best Management Practices for Illicit Discharge Elimination 14

3-4 Best Management Practices for Construction and New Development 18

3-5 Menu B Candidate BMPs $\quad 21$

3-6 Menu C Candidate BMPs 32 
The purpose of this report is to provide operators of municipal storm water systems with the information needed to evaluate a series of candidate Best Management Practices (BMPs), formally select BMPs that would be most effective in dealing with local conditions, and begin the process of developing effective implementation plans. It is difficult to develop an entirely successful plan, and more than one iteration may be required. The BMPs presented here as candidates have been "pre-screened" and "prequalified" by the consulting team--i.e., they are known to be worthy of consideration for addressing the problems and conditions that exist in the watersheds that contribute storm water runoff to Santa Monica Bay. In this report, we have recommended a set of BMPs that we feel should be implemented, along with those that we feel should be carefully considered for inclusion in a Santa Monica Bay Watershed Management Plan.

The formal selection process described herein is recommended because local opportunities, constraints, priorities, and other factors need to be taken into account by local decision makers before specific BMPs are selected and implemented. Furthermore, use of a formal, well-documented evaluation and selection process is prudent in circumstances where program decisions and resource commitments may come under scrutiny or challenge.

This report covers information that was presented in abbreviated form during a workshop that was held in Santa Monica on June 14, 1992. The workshop and this report were developed and presented to the municipal storm water co-permittees by personnel from Woodward-Clyde Consultants (WCC) and University of California at Los Angeles (UCLA) on behalf of the Santa Monica Bay Restoration Project.

\subsection{BACKGROUND}

After many years of conducting technical studies to assess the importance of urban storm water discharges as a source of water pollution, the US. Environmental Protection Agency (EPA) issued a set of draft regulations in December 1988. These draft regulations were intended to initiate and guide municipal programs for identifying and controlling pollutants that are carried through and discharged from municipal separate storm sewer systems. The regulations were issued in draft form to provide interested parties (e.g., municipal storm water dischargers, commercial and industrial interests, state and regional water quality control agencies, public interest groups, and the general public) the opportunity to review the requirements and provide comments that would guide the final rule-making process. The final rule, which is a part of EPA's National Pollutant Discharge Elimination System (NPDES), was issued by EPA in November 1990 and requires most sizable cities (based on population) in urbanized areas nationwide (as well as some industries) to conduct technical studies, identify and assess sources of storm-water-borne pollutants, and implement practical pollution controls in the form of BMPs.

During the period when EPA's draft regulations were being subjected to public review and comment (i.e., December 1988 to November 1990), several California cities, counties, flood control districts, the US EPA, the State and regional water quality control boards, and other public entities joined together in various regional consortia and developed strategies that would allow them more flexibility than the emerging federal regulations were 
thought to provide. These so-called "early permitting" strategies were worked out by eight groups of co-applicants in Northern, Central, and Southern California and were approved by EPA Region 9 and the respective Regional Water Quality Control Boards (RWQCBs). The resultant early permits were issued under then-existing NPDES permit structures (i.e., before the storm-water-specific regulations came into effect in November 1990). In most respects, the early permits issued for Southern California municipal storm water dischargers have similar requirements to the programs being pursued elsewhere in the United States,, but there are two important differences:

- $\quad$ For one, the co-permittees were given a longer time period to conduct most of the studies and planning efforts. Most sizable US. cities are required to complete their studies and planning before applying for permits in November 1992 or May 1993 (depending primarily on the size of the respective municipal separate storm sewer systems), whereas the Southern California early co-permittees are allowed to conduct the studies and planning efforts during the 5-year term of their NPDES permits.

- $\quad$ Second, the Southern California co-permittees were required to select and implement certain "early action best management practices" from the outset and then conduct studies and more definitive planning efforts to select and implement additional BMPs in accordance with schedules worked out with their respective RWQCBs.

During the past few years, representatives of many cities, county agencies, environmental organizations, other public interest groups, and many interested citizens and regulatory agency personnel have worked cooperatively and proactively to protect and restore water quality and beneficial uses in Santa Monica Bay. The efforts and accomplishments of the Santa Monica Bay Restoration Project, Heal the Bay, the LA-RWQCB, and others that have worked to address challenging water quality management issues, have been considerable. Their actions should not be seen as being driven by the NPDES storm water permitting process, because they have had other specific water quality improvement goals as their primary motivation. Nonetheless, there are numerous ways in which the programs have come together. This report and the June 15, 1992 workshop that preceded it are examples of how the Restoration Project and the so-called "early co-permittees" have worked together to plan appropriate BMPs.

\subsection{REPORT ORGANIZATION}

This document is organized into four sections. Section 1.0 (this section) provides the background needed to understand why this report was written and provides an overview of the regulatory framework. Section 2.0 provides insight on the ideas and concepts usually associated with BMPs and acts as a back drop for the rest of the report. Section 3.0 discusses the various BMPs, recommends BMPs that should be implemented now, and provides a mechanism for selecting future BMPs. Section 4.0 discusses what should be done in the future. 
As described in Section 1.1, over 80 cities and the County of Los Angeles are parties to an "early" NPDES permit that is intended to reduce the amounts of pollutants that enter storm water conveyance systems and receiving waters. The co-permittees that manage storm waters that discharge into Santa Monica Bay have identified existing Best Management Practices (BMPs) and instituted easily implementable BMPs. For the most part, these were practices that were either already in place (i.e., before the permit requirements came into effect) or are some variations of the pre-existing public works operations and maintenance programs (e.g., storm inlet inspection and cleaning, street cleaning, litter control). In 1991, the co-permittees developed and submitted reports (to the Los Angeles-Regional Water Quality Control Board), documented their existing programs, looked for ways to modify, refine, or intensify their practices to obtain greater storm water quality benefits, and planned early action storm water BMPs. The purpose of this early action phase was to assure that significant controls would be implemented as quickly as possible, but the copermittees were aware that additional controls could also be needed. This section describes some principles that should be considered as co-permittees continue their efforts to evaluate local conditions and select among candidate supplementary controls.

Section 3.0 presents a structured process that is recommended for co-permittees' use for evaluating and selecting among candidate BMPs. Specifically, section 3.3 presents a sizable, pre-screened list of BMPs to consider as candidates and describes several factors that co-permittees should take into account in their selection process. The pre-screening was performed by Woodward Clyde Consultants with the assistance of the Santa Monica Bay Project staff and Technical Advisory Committee members. These concepts of prescreening, evaluation factors, and the use of a formal structural process warrant some introduction, and that are the subject of Sections 2.2,2.3, and 2.4.

\subsection{PRE-SCREENING}

The importance of urban storm water as a cause of water pollution has become apparent in some parts of the country earlier than others. This is largely because of the broad variety of hydrologic conditions and pronounced differences in receiving water conditions from area to area within the US. As a result, water quality programs in some areas have been working with storm water BMPs for many years. Fortunately, many of these BMPs have been studied to assess their performance, practicality, and costs; and this information is available for consideration by local decision-makers.

The BMPs presented herein have been selected (by Woodward-Clyde and UCLA) from a long list of storm water controls that have been used (or considered for use) in other urban locations nationwide. The pre-screening that led to the list of BMPs presented for consideration in the Santa Monica Bay area was performed in two steps, as follows:

- The first step involved eliminating BMPs that would have little or no application, given local climatic and land-use conditions. This step eliminated BMPs related to de-icing, snow removal, and control of agricultural practices (e.g., large-scale use of pesticides, herbicides, fungicides, erosion controls, poultry and livestock management, and 
agricultural waste management). BMPs targeted toward these types of practices are common in significant parts of many urban areas, but are not seen as being relevant in the Santa Monica Bay area.

The second step involved establishing a philosophical bias in favor of pollution prevention (i.e., source control) and in favor of building upon a manageable number of existing programs. The concept of "pollution prevention" or "source control" implies that one should emphasize BMPs that keep pollutants out of storm water, rather than trying to remove pollutants that have already entered storm water or the receiving waters. Some source controls are structural (e.g., providing roofs to keep precipitation off of exposed storage piles, providing berms to keep site runoff away from storage piles), but most source controls are nonstructural. They typically include the use of educational programs aimed toward changing people's awareness and behavior (especially regarding the proper use and disposal of household and automotive products), the use of local ordinances and inspection programs focused on identifying and converting illicit connections and illegal dumping, and the use of public works programs focused on improved "housekeeping" of public infrastructure (e.g., street sweeping, litter control, storm inlet and storm drain cleaning, channel maintenance, fleet maintenance).

\subsection{EVALUATION FACTORS}

The BMP evaluation and selection process described in Section 3.0 involves considering several "factors" which are intended to provide a means for incorporating the decisionmakers' preferences, priorities and constraints. It is recognized that the co-permittees in the Santa Monica Bay area are all public agencies that must function within a context of: limited resources; multiple (often conflicting) demands; pre-existing obligations, commitments, and constraints; and political tensions. The requirement for intensified storm water control at the municipal level is only one of many requirements each co-permittee must deal with. Therefore, each co-permittee agency needs to carefully consider a variety of factors that reflect local social, political, environmental, and fiscal realities--because these combine to define what is "practicable" in their real-world setting. Section 3.3 describes 13 factors which are intended to help decision makers consider the following: environmental implications, effectiveness regarding pollutants of concern, implementing agency/department acceptability, regulatory requirements, public acceptance, risk/liability, fairness, reliability, sustainability, universality, implementation cost, flexibility for phased implementation, and ability to demonstrate compliance.

\subsection{FORMAL EVALUATION AND SELECTION PROCESS}

Section 3.0 presents a formal method for evaluating and selecting appropriate BMPs for several reasons, all of which are related to the concept that the decision makers within any given co-permittee agency may be pressed to explain (or even defend) the basis for their evaluations and selections. The need to explain their decision process may come from any of several sources, including:

- The selected BMPs will have some degree of impact on municipal services that public agencies can provide. Members of the public, interest groups, elected or appointed officials, and/or department heads may challenge (or at 
least inquire about) the rationale for committing public resources toward specific aspects of storm water quality control.

- Some of the BMPs will require certain parties (e.g., residents, commercial/industrial establishments, institutions, public agencies) to do things they do not want to do (or to stop doing things they want to do). Therefore, some people will not be pleased with the selected BMPs and may challenge the basis for their selection.

- $\quad$ On the other hand, there are those who would like to see additional (or at least more intensive) BMPs and may challenge the basis for limiting the copermittees' obligations to only the selected BMPs.

It should be clear that the best defense against even an informal challenge would be to avoid as much as possible the allegation of having been arbitrary and capricious by employing the following strategies from the outset:

- involve the right people at the appropriate times in the process of evaluating and selecting BMPs.

- Employ relevant and appropriate information so the decision makers do not have to operate in a vacuum regarding key issues.

- Establish and follow a rational, formal decision process that is welldocumented throughout. Section 3.3 describes a process that meets these objectives.

\subsection{LAND-USE AND WATER QUALITY CONCERNS}

It is important that decision makers have an understanding of the land-use and water quality considerations from which to base the evaluation of the BMPs on. This section presents a brief discussion of land-use considerations with regard to pollutant loadings to the Bay and a discussion of water quality parameters of concern.

\subsubsection{Land-use Considerations for Selection and Targeting of BMPs}

In development of the loadings model for Santa Monica Bay, the land-use data available from the Southern California Association of Governments was utilized. These land-uses included:

- $\quad$ Single Family Residential,

- Multi-family Residential,

- Commercial,

- $\quad$ Public (schools, government offices),

- Light industrial,

- Other urban (not included above),

(parks, undeveloped land), and

- Unknown.

The NURP program developed estimates of typical runoff concentrations in urban areas for commercial, residential and open land uses. Other programs have been developing data for 
industrial runoff, although industrial runoff would be expected to vary considerably with the type of industry present.

The Santa Monica Bay Storm Drainage Pollutant Model was used to develop initial loading estimates based upon NURP data for runoff concentrations, which was adjusted based local data summarized in the loadings model report (Stenstrom and Strecker, 1993). Localized data for rainfall, land-use type, and percent impervious (estimated based upon land-use) was utilized to develop loading estimates.

Because of the large area of residential land-use in the watershed ( 33 percent), this land-use was found to be the highest contributor of pollutants to the Bay. Commercial areas constitute 3 percent and light industrial 2 percent of the total Bay watershed, as a comparison. However, because of their usually higher percent impervious areas and higher concentrations, commercial and industrial areas have a much higher unit area loading rate. Therefore, targeting of structural control measures in these areas would result in the highest pollutant removals per unit cost. Watershed-wide source control measures are warranted in existing residential land-uses.

Highway runoff is another likely large source of pollutants to the Bay. Because the data was not available, highways were not individually modeled. The FHWA studies (FHWA, 1990) found that in general, pollutant concentrations for heavy metals were 2 to 4 times higher in highway runoff than general urban runoff. Combined with their higher percent imperviousness, focusing on controlling pollutants from freeways and highways would also be warranted. In addition, automotive repair shops have been targeted by many other programs (Santa Clara, Bellevue) due to their expected higher contribution of pollutants.

New construction is a target that is specifically called out for action in the NPDES regulations. Both in terms of controlling erosion of soils, but also for designing and building best management practices to control pollutants from these areas. For example, in new construction the use of grass swales rather than piped drainage would improve water quality and lead to lower piping costs. Open land comprises a great fraction of certain watersheds, such as in the Malibu and Las Virgines areas. BMPs to mitigate the impacts of construction could be especially important in these areas.

\subsubsection{Water Quality Parameters}

Key water quality parameters that are of concern to urban nonpoint source runoff have been analyzed in many studies of urban runoff. Some pollutants have been identified as causing problems in receiving waters while other parameters have not routinely been detected or have been detected in concentrations which have not indicated that problems exist. The water quality parameters analyzed in many studies, including the Nationwide Urban Runoff Program (US EPA 1983), Santa Clara and Alameda Runoff Studies and the City of Portland Study include solids, nutrients, heavy metals, hydrocarbons, oil and greases, pesticides, herbicides, volatile organics, and oxygen demand.

The following briefly describes the groups of pollutants which typically have been found to be of concern and warrant attention in the development of plans to reduce pollutant loadings to receiving waters. These pollutants are based on the results of past sampling in the local area (Stenstrom and Strecker, 1993) and on the results of several major runoff water quality studies. These studies were conducted by Woodward-Clyde Consultants (WCC) for the Environmental Protection Agency (US EPA, 1983), Federal Highway Administration (FHWA, 1990), Santa Clara and Alameda Counties, and the Cities of Portland and Eugene. 
Total Suspended Solids (TSS) The term "suspended solids" is descriptive of the organic and inorganic particulate matter which is of a size and type that allows the particles to stay suspended in water. The sediment load in a water body is influenced by a number of factors including but not limited to: particle size, stream flow, climate, geology, and vegetation of each drainage system. The conditions under which suspended sediments are considered a pollutant is a matter of definition. In general, suspended solids are considered a pollutant when they significantly exceed natural concentrations and have a detrimental effect on water quality and/or beneficial uses of the water body. Suspended sediments are often used as a indicator for other contaminants which bind easily with fine particulate matter, including heavy metals and phosphorus.

Sediment loads have been considered a problem in most all urban runoff studies, both due to their direct problems (siltation, aquatic life respiration inhibition, etc.) and their transport of other pollutants. On the other hand, sediments from natural areas provide sands for beaches, providing critical habitat. Therefore, in Santa Monica Bay, sediments from urban surfaces and from construction should be targeted, rather than natural unaccelerated erosion from undisturbed areas.

Nutrients. Nutrients are necessary for the growth and support of biota in natural water systems. Excessive quantities can over-stimulate biological growth and create objectionable water quality conditions. Runoff from fertilized areas and discharges of sewage or industrial wastes are frequently sources of significant quantities of nutrients. Other sources include urban storm water runoff and direct atmospheric deposition to water body surfaces. In general, the most important nutrient factors causing an acceleration in algae production are nitrogen compounds and phosphorus.

Nutrients have not been identified as a general problem in Santa Monica Bay. In fact the Bay is considered nutrient poor. However, urban runoff is a significant source of nutrients to receiving waters. Therefore, nutrient controls should be considered to control "localized" problems for identified receiving waters. These could include Malibu Lagoon and Marina del Rey.

Heavy Metals. Heavy metals such as copper, lead, and zinc are naturally released in very small quantities by the weathering of exposed soils and mineral deposits, corroding metal surfaces, decomposing paints, and certain corrosion-control compounds. Vehicles are sources of heavy metals. Lead from leaded fuels is a very important source. Tires can contain significant quantities of zinc. Catalytic converters are also potential sources. Heavy metals tend to have comparatively low solubility and are often mobilized by forming soluble complexes with humic materials or by becoming attached to suspended solids.

These metals are present in the biosphere as trace elements and are micronutrients necessary for plant and animal growth. Heavy metals are of concern because elevated concentration levels of soluble forms in natural water bodies can produce toxic effects in biota. Sources include regulated domestic and industrial point-source discharges, urban storm water runoff, and direct atmospheric deposition.

The most frequently detected pollutants in the NURP study were lead (94 percent), zinc (94 percent), and copper ( 91 percent). Chromium and arsenic were detected in 58 and 52 percent of the samples, respectively. Of the inorganic pollutants, lead, zinc, and copper exceeded criteria most often. In Portland, cadmium, nickel, and silver have also been identified as heavy metals of concern. However, in looking at treatment based controls the conclusions drawn from the analysis of lead, zinc and copper can be used to indicate the behavior of other heavy metals. For source controls, specific parameters may require 
individual analysis and planning. For instance, a likely source of silver in storm drains could be discharges from photographic laboratories. The State of the Bay report has indicated that there are elevated heavy metals in the sediments of the Bay, including elevated lead levels in sediments of Marina del Rey. In addition, the data developed and analyzed for this study of Santa Monica Bay (Stenstrom and Strecker, 1993) indicated that observed metals levels during storm events were significantly higher than NURP concentrations for lead and zinc. There was not enough data on other metals to make such comparisons, but they are likely high as well. Heavy metals are considered a potentially significant problem. The proposed monitoring program for storm water drainage in Santa Monica Bay should further identify the significance of heavy metals being discharged to Santa Monica Bay.

Oxygen Demand. Oxygen demand refers to the amount of oxygen that will be consumed by biological or chemical reactions involving organic and inorganic compounds. In general, moderately high dissolved oxygen content is necessary for the maintenance of healthy aquatic ecosystems. The relationship of oxygen-consuming discharges to the amount of dissolved oxygen in a receiving water body, therefore, is fundamental to the maintenance of environmental quality in natural water bodies.

Oxygen demand is measured in terms of Biochemical Oxygen Demand (BOD) and Chemical Oxygen Demand (COD). The BOD test provides an indirect measure of the quantity of biologically degradable organic matter in water in terms of the amount of oxygen required by microorganisms to oxidize it to carbon dioxide and water. The COD test measures the consumption of oxygen from a strongly oxidizing chemical agent.

In urban storm water COD levels are typically found to be about 8 times greater than BOD levels, indicating that much of the demand does not come from easily biodegradable materials. Stormwaters are often close to saturation DO concentration, and in some cases during low flow can be supersaturated due to photosynthesis. BOD and COD generally take several days to have impacts on receiving waters. It is likely that the Santa Monica Bay does not have significant oxygen deficits due to BOD and COD, but that localized problems could occur in smaller receiving waters such as Malibu Lagoon and possibly Marina del Rey.

Aesthetics. This category of pollution refers to litter, floatables, odor, scum, algae, bubbles, color(s), marine debris, and riparian vegetation impacts. Some of these inhibit habitat values, while others detract from human enjoyment or cause possibly safety problems. These pollutants have been identified as a problem in Santa Monica Bay.

Organic Pollutants. In the NURP program it was found that 63 of a possible 106 organics analyzed were detected in urban runoff. However, in general, organic pollutants exceeded applicable EPA water quality criteria much less frequently than inorganic pollutants. Of the pesticides analyzed, only 4 had a frequency of detection greater than 10 percent. These ranged in frequency of detection from 15 to 20 percent, and exceeded criteria from 8 to 17 percent of the time. Four polycyclic aromatic hydrocarbons (PAHs) were detected in urban runoff, but did not exceed EPA's freshwater life criteria. Only one form of PCB was detected (PCB-1260) and that was only a single detection. DDT was found in less than one percent of samples analyzed. The Portland study has found that organics are not generally a problem in storm water. There are however instances of pesticide concentrations in sediments. PAHs have also been detected in concentrations which exceeded the new Washington State standards. 
Given that these constituents have not been found in quantities to warrant significant attention, they probably should receive less attention at this time. However, it is recommended that the Santa Monica Bay Monitoring Plan be implemented so that these parameters can be evaluated locally at an appropriate frequency until their presence or absence is determined. These parameters still warrant attention in the form of education and minimization of use; however, banning the use of pesticides and herbicides is not warranted.

Oil and Grease. Oil and grease is a prevalent constituent in urban runoff. In a study of oil and grease concentrations in urban runoff in Richmond, California, Stenstrom et al. (1984) found that oil and grease concentrations in runoff from commercial properties and parking lots are about three times higher than from residential and open areas. The NURP program did not address oil and grease. Accurately measuring oil and grease is very difficult, especially due to its affinity for coating sampling bottles and tubing. Furthermore, separating oil and grease from anthropogenic (man made) and biogenic (naturally occurring) sources is not easy to do, but has a major impact on its potential impact. Eganhouse and Kaplan (1981) measured oil and grease concentrations in the Los Angeles River and found that concentrations were generally lower during storm events than during dry flows. The State of the Bay report $(\mathrm{MBC}, 1988)$ estimated that urban runoff accounted for about 3 percent of the total input of oil and grease to the Bay. Recent data in Portland has found relatively low levels of oil and grease contamination. However, it is considered a problem by the public, and is sometimes visually apparent in Santa Monica Bay drainage channels, such as Ballona Creek. Therefore, it warrants a modest amount of attention in implementation of BMPs, including programs to avoid or prevent illegal dumping.

Pathogens. The State of the Bay report (MBC, 1988) indicates that during storm events, indicators of pathogens increase (fecal coliform, enterococcus), but it is uncertain whether these are primarily from animal or human wastes. Studies in Portland, Santa Clara, Alameda, Eugene, and Seattle have shown that these bacterial measures increase during storm events. In addition, on-going local studies sponsored by the Santa Monica Bay Restoration Project have shown storm drains to be a source of these indicator parameters as well as human viruses. Therefore, in Santa Monica Bay the concern for human health due to pathogens has become a concern. It is important to note that there have been many incidents of the direct release of sewage into Ballona Channel and other drainage facilities during failures of the sewer system and these direct releases more than nonpoint source runoff may be a contributor to pathogen problems. A program to locate sanitary sewer and stormdrain cross connections, including an aggressive field screening program to locate problem outfalls, is warranted. 
BEST MANAGEMENT PRACTICES SELECTION PROCESS

Numerous storm water Best Management Practices (BMPs) have been developed, implemented, and evaluated over the last 20 years. Some of these BMPs specifically meet the requirements prescribed in EPA's NPDES regulations, and others are simply considered beneficial for controlling storm water. These BMPs have been pre-screened because not all of them are appropriate for use in the Santa Monica Bay area.

The following sections describe certain BMPs that should be implemented and provides the tools to select other BMPs that will be useful in controlling storm water pollution.

\subsection{THE MENU CONCEPT}

In the Santa Monica Bay area, municipal co-permittees are required to implement various BMPs to help control pollutants that would otherwise be discharged via their storm sewer systems. The program being guided by the Los Angeles Regional Water Quality Control Board is intended both to provide the co-permittees with the freedom to select BMPs that are appropriate to local conditions, and to assure that all co-permittees implement enough controls to achieve a meaningful level of pollution prevention.

The three-element "menu" system described herein provides a basis for balancing flexibility and assurance of meaningful control. The following discussion explains the menu system-first in direct terms, then by analogy, and then through a simple example.

Co-permittees are being provided with three lists of candidate BMPs for possible implementation in their respective jurisdictions. These lists (referred to herein as "menus") differ from one another in terms of the degree of obligation associated with each. As explained in detail below, the BMPs on Menu A are "mandatory," the BMPs on Menu B are "recommended," and those on Menu C are entirely "optional." During the process of developing local (i.e., city-specific) storm water management plans, the co-permittees will consider all three menus, but will only have to select BMPs from Menu A and Menu B. More specifically, they must select all BMPs on Menu A, but they need to select only the most appropriate BMPs from Menu B. Some co-permittees may decide to include additional BMPs from Menu C, but others may decide not to include any from Menu C. The hierarchy of obligation can be summarized as follows:

Menu A - Mandatory - All co-permittees are required to select and implement all of the BMPs listed on Menu A, because there is sufficient evidence that these BMPs would be effective in controlling water pollution problems in the Santa Monica Bay watershed area.

Menu B - Recommended - All co-permittees are required to consider all of the BMPs listed on Menu B, because they have a high likelihood of being effective if properly implemented. However, the co-permittees do not have to select or implement all Menu B BMPs, if the rejected BMPs would not be practicable or warranted (given local circumstances, conditions, and constraints) and that the selected BMPs are believed to be sufficient to control storm water pollution. That is, the burden of proof for not selecting a BMP from Menu B lies with the copermittee. 
Menu C - Optional - Co-permittees will be provided with an inventory of ideas to consider but are under no obligation to select or implement any of the BMPs from Menu C. The concepts listed on Menu $C$ have been explored and/or implemented in other storm water pollution control programs, but they are provided here only as a resource to facilitate the planning process. It is likely that some copermittees may decide to pursue one or more of the Menu C BMPs (perhaps because they may represent an opportunity to solve a local problem or because they may make good use of local resources or they would be more likely to be successful than a measure in Menu B for a given problem), but the co-permittees do not have any burden of proof for demonstrating why they did not select Menu C BMPs.

The concept of using a hierarchy of lists to structure a decision-making process has broad application. The most obvious application is the source of the term "menu." Patrons in a restaurant are presented with options in a way that facilitates matters for both the customers and the restaurant staff. Some would consider Menu A and Menu B to consist of items that are the "main course" on a menu, whereas Menu C contains "appetizers" or "dessert" items. Perhaps a more apt analogy would be the lists of courses in a college catalog. Menu A corresponds to the "core courses" that are mandatory curriculum requirements for graduation. Menu B corresponds to the courses that pertain to a particular major or are part of the standard curriculum for a degree from a particular department. Menu C corresponds to "elective" courses that a given student might take to round out their education or to build upon some particular talent. Continuing this analogy, credit would be given for every course the student takes (i.e., every BMP that is implemented), but only certain courses are obligatory.

The above-described menu system will be used in the Santa Monica Bay area to structure the process by which co-permittees evaluate, select, and implement BMPs. The BMPs that have been considered appropriate to designate as "mandatory" are listed on Tables 3-1, 3-2, 3-3, and 3-4. Again, these Menu A BMPs are well understood, by virtue of having been used with notable success in many areas. They are also believed to be cost-effective for dealing with the kinds of pollutants and conditions that exist in the Santa Monica Bay area. Furthermore, it is relatively easy for them to be implemented in compliance with the regulatory requirements of a Municipal Storm Water Management Program, as defined by the Environmental Protection Agency's (EPA's) current regulations.

\subsection{MENU A BMPs}

Several BMPs have been designated as being of high priority for implementation. These BMPs are to be considered mandatory by all participants in the Santa Monica Bay watershed. The Menu A BMPs focus mainly on education construction, industry, and illicit connections/illegal dumping controls.

\section{Public Education}

The central goal of public education is to reduce the amount of pollutants entering Santa Monica Bay through the storm drain system by informing the public about the causes of storm water pollution (i.e., pollutant sources and pathways) and by encouraging public involvement in reducing the storm water pollution. Public education can also teach the proper use and management of potential pollutants so they do not end up in the storm water conveyance systems. 
Table 3-1. Best Management Practices For Public Education.

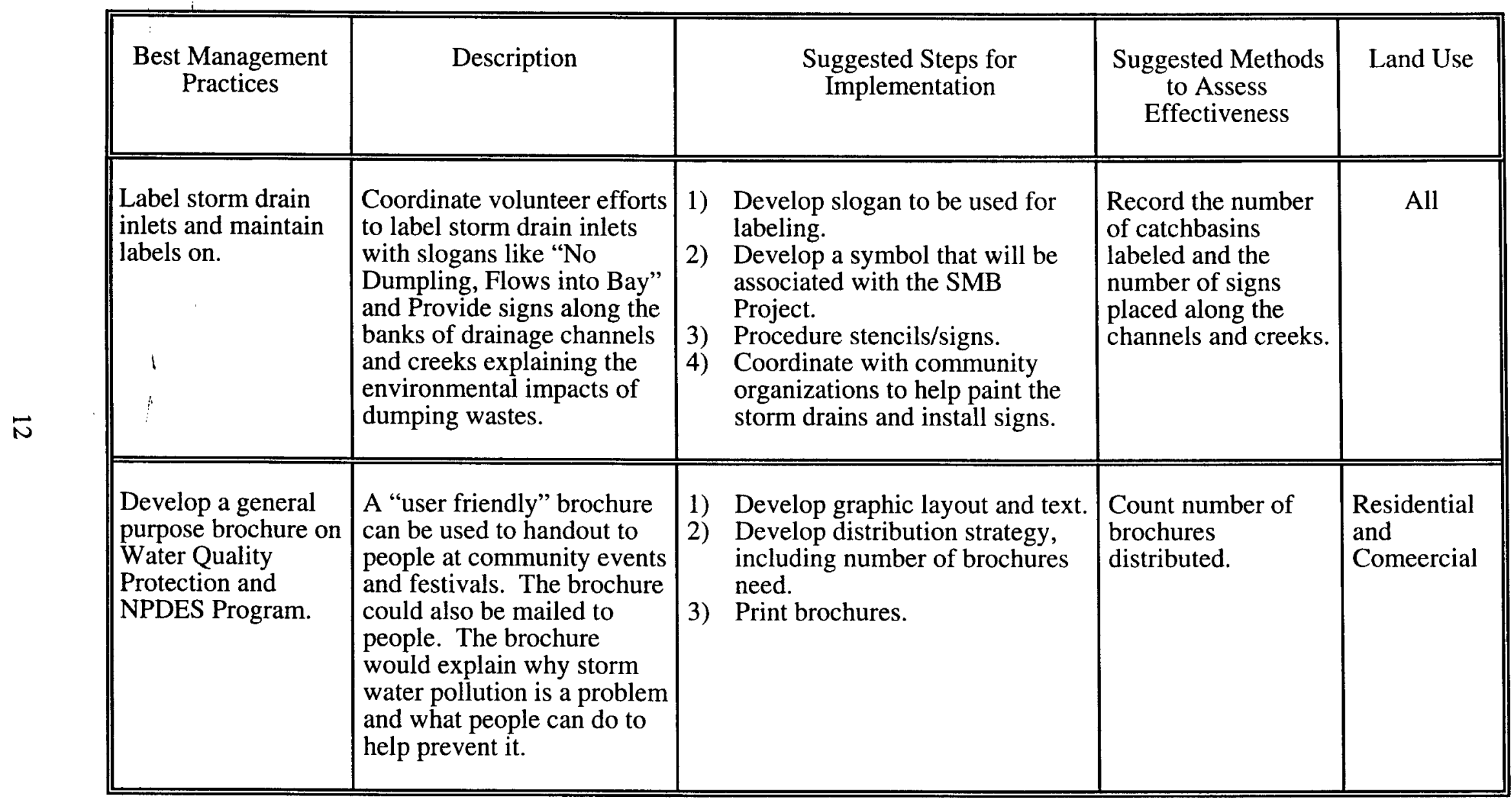


Table 3-2. Best Management Practices for Industrial Facilities.

\begin{tabular}{|c|c|c|c|c|}
\hline $\begin{array}{l}\text { Best Management } \\
\text { Practices }\end{array}$ & Description & $\begin{array}{l}\text { Suggested Steps for } \\
\text { Implementation }\end{array}$ & $\begin{array}{l}\text { Suggested Methods } \\
\text { to Assess } \\
\text { Effectiveness }\end{array}$ & Land Use \\
\hline $\begin{array}{l}\text { Assist industries to } \\
\text { comply with general } \\
\text { Permits. }\end{array}$ & $\begin{array}{l}\text { Some industries may be } \\
\text { unfamiliar with laws which } \\
\text { requires SWPPP } \\
\text { preparation at individual } \\
\text { facilities. The appropriate } \\
\text { agency should advise such } \\
\text { industries of the State and } \\
\text { Federal requirements. }\end{array}$ & $\begin{array}{l}\text { 1) Examine SWPPPs for } \\
\text { completeness. } \\
\text { 2) If SWPPPs are unavailable, } \\
\text { advice the facility of State } \\
\text { requirement and document } \\
\text { advice with Regional Water } \\
\text { Quality Board. } \\
\text { 3) Assist facilities to prepare } \\
\text { SWPPPs. } \\
\text { 4) Provide facilities with sample } \\
\text { SWPPPs. }\end{array}$ & $\begin{array}{l}\text { Record number of } \\
\text { industries that violate } \\
\text { Storm Water } \\
\text { Regulations and/or } \\
\text { require assistance to } \\
\text { prepare SWPPPs. }\end{array}$ & Industrial \\
\hline
\end{tabular}


Table 3-3. Best Management Practices for Illicit Discharge Elimination.

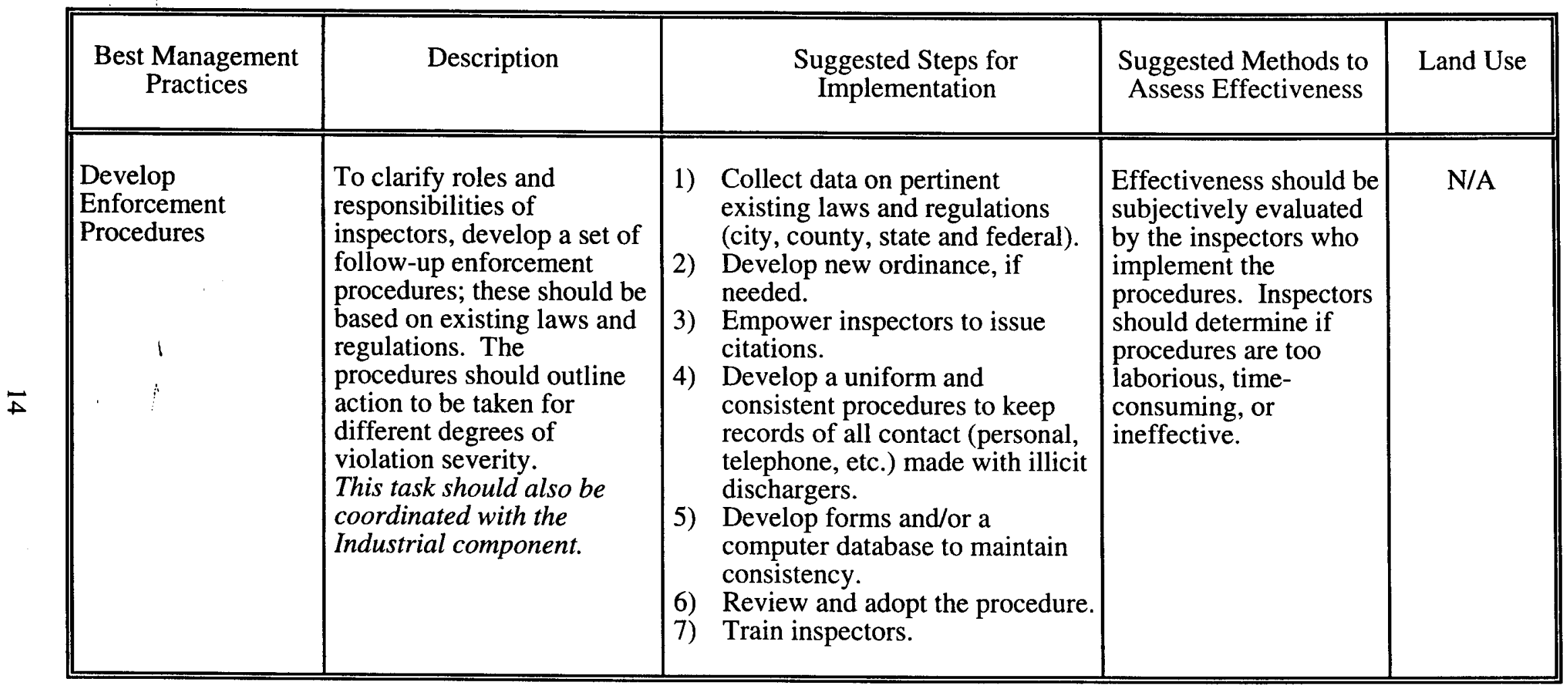


Table 3-3. Best Management Practices for Illicit Discharges Elimination.

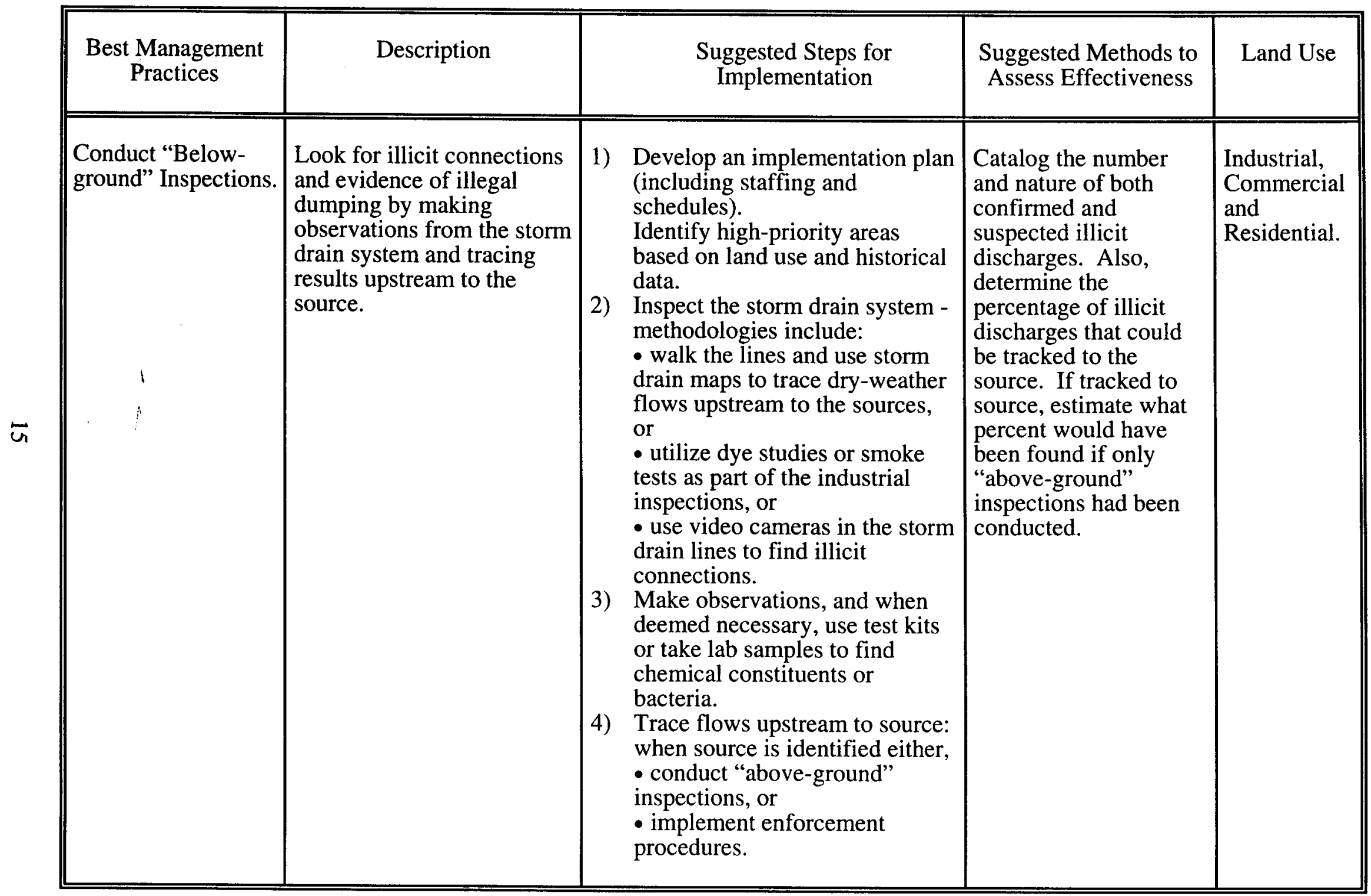


Table 3-3. Best Management Practices for Illicit Discharge Elimination.

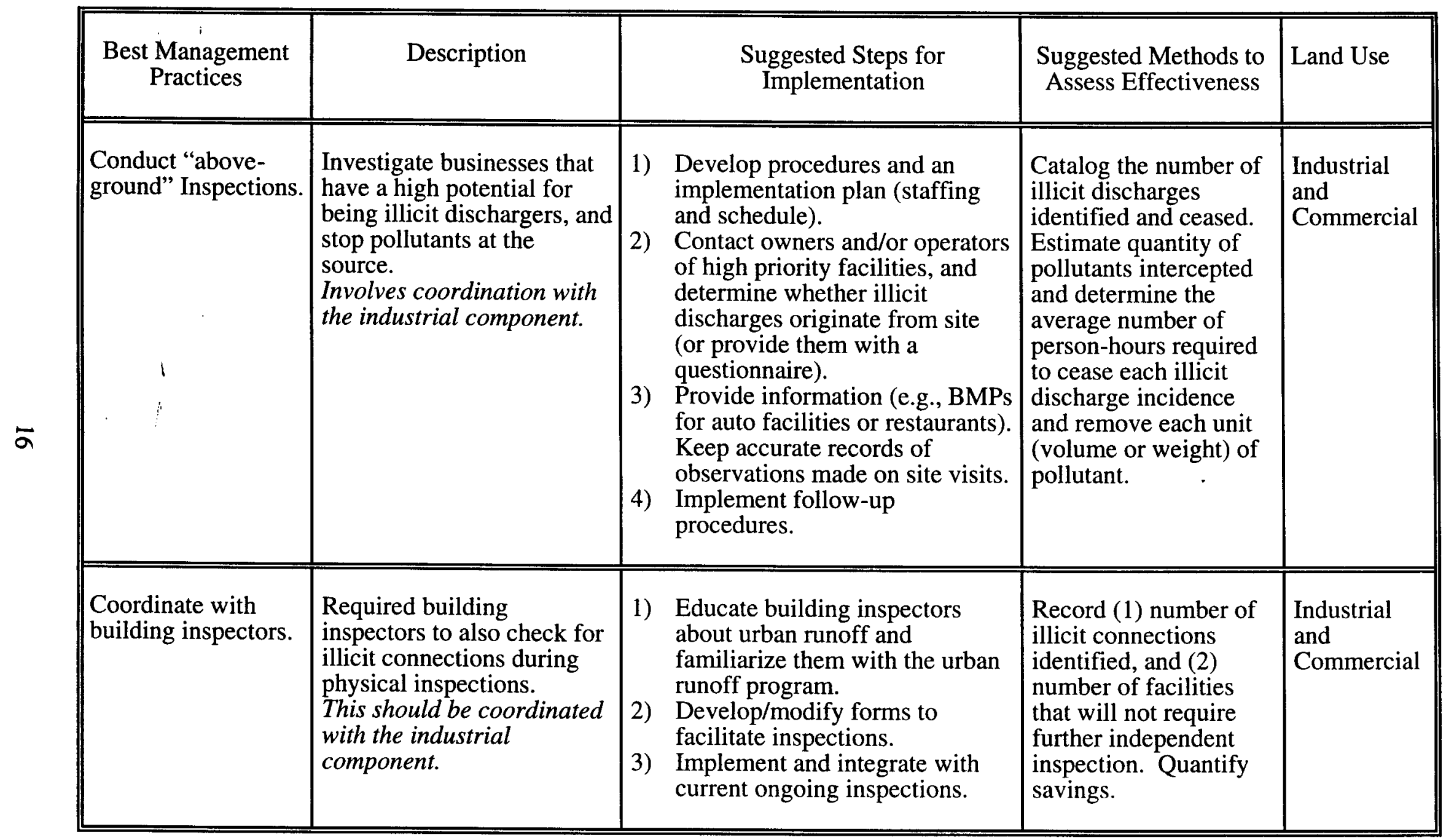


Table 3-3. Best Management Practices for Illicit Discharge Elimination.

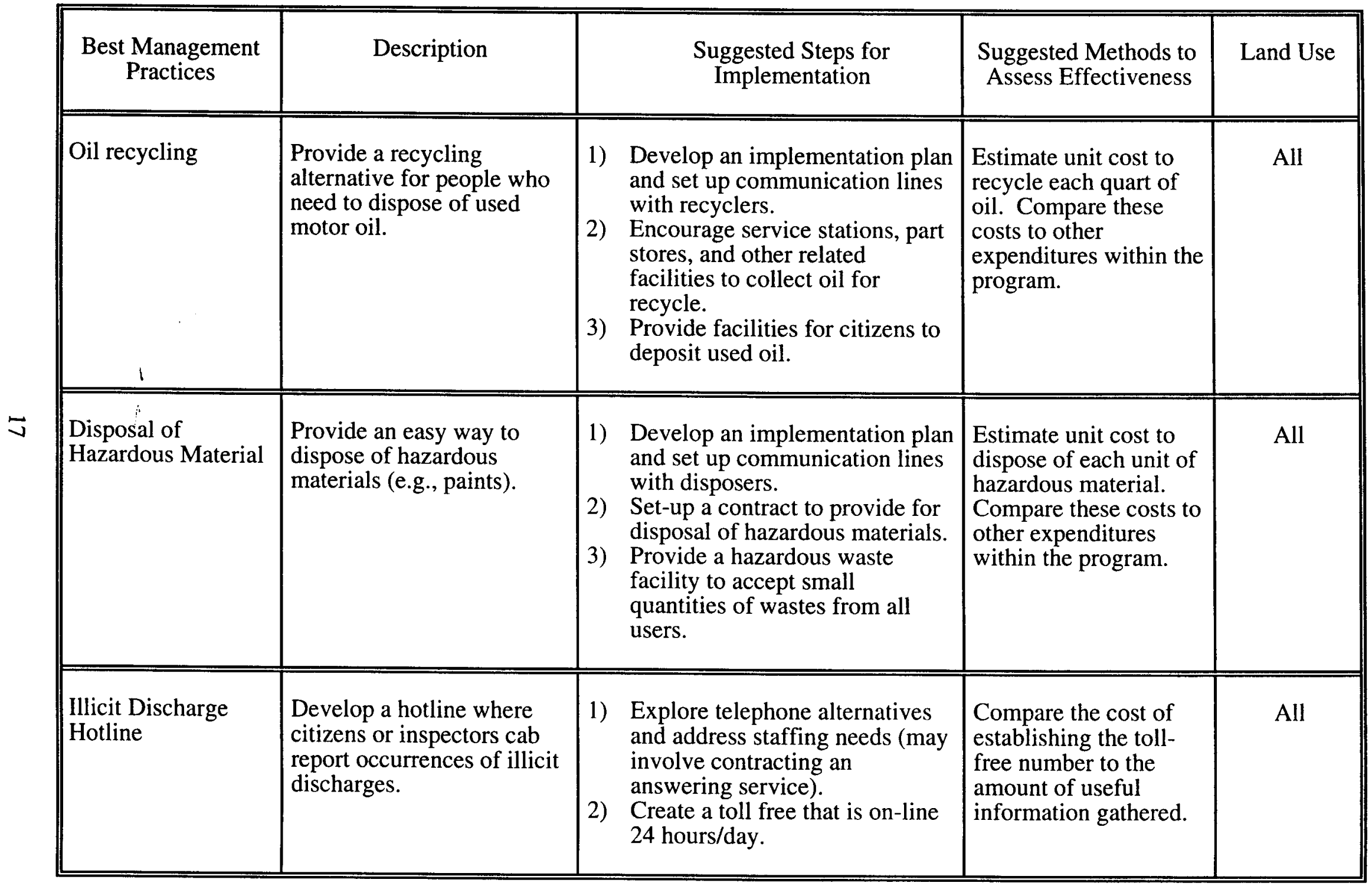


Table 3-4 Best Management Practices for Construction and New Development

\begin{tabular}{|c|c|c|c|c|}
\hline $\begin{array}{l}\text { Best Management } \\
\text { Practices }\end{array}$ & Description & $\begin{array}{l}\text { Suggested Steps for } \\
\text { Implementation }\end{array}$ & $\begin{array}{l}\text { Suggested Methods to } \\
\text { Assess Effectiveness }\end{array}$ & Land Use \\
\hline $\begin{array}{l}\text { Insure that } \\
\text { Construction } \\
\text { SWPPP are } \\
\text { complete }\end{array}$ & $\begin{array}{l}\text { Provide an inspection } \\
\text { program to insure that } \\
\text { SWPPPs are complete. }\end{array}$ & $\begin{array}{l}\text { Training Building Department } \\
\text { on how to check Construction } \\
\text { SWPPP. } \\
\text { 2) Require submittal of a copy of } \\
\text { SWPPP with application for } \\
\text { Building Permit. }\end{array}$ & $\begin{array}{l}\text { Record the number of } \\
\text { SWPPPs checked. }\end{array}$ & All \\
\hline $\begin{array}{l}\text { Publicize the } \\
\text { existence and } \\
\text { encourage the use of } \\
\text { a Guidance Manual } \\
\text { for construction } \\
\text { industry }\end{array}$ & $\begin{array}{l}\text { Currently, in California, } \\
\text { construction activity } \\
\text { disturbing acres or more } \\
\text { need to develop a SWPPP. } \\
\text { A guidance document } \\
\text { describing the process of } \\
\text { developing a SWPPP and } \\
\text { recommending BMPs } \\
\text { should be developed. }\end{array}$ & $\begin{array}{l}\text { 1) Publicize a Guidance Manual. } \\
\text { Conduct workshops to } \\
\text { encourage users. }\end{array}$ & $\begin{array}{l}\text { Record the number of } \\
\text { construction industry } \\
\text { representatives } \\
\text { attending workshop or } \\
\text { requesting manual. }\end{array}$ & All \\
\hline $\begin{array}{l}\text { Develop Guidance } \\
\text { Manual for New } \\
\text { Development }\end{array}$ & $\begin{array}{l}\text { To prevent increased storm } \\
\text { water pollution associated } \\
\text { with new development, a } \\
\text { Guidance Manual } \\
\text { describing BMPs should be } \\
\text { developed. }\end{array}$ & $\begin{array}{l}\text { 1) Collect and develop New } \\
\text { Development BMPs. } \\
\text { 2) Compile a Guidance Manual. } \\
\text { Present manual at a workshop. }\end{array}$ & $\begin{array}{l}\text { Record the number of } \\
\text { developers attending } \\
\text { workshop or requesting } \\
\text { manual. }\end{array}$ & All \\
\hline
\end{tabular}


There are several educational BMPs that can be implemented to help reduce storm water pollution. Although their goals are related, they are diverse in terms of the audiences and pollutant types they address. Since Menu A BMPs are considered mandatory, only a few BMPs which would be beneficial to the whole watershed have been designated. Other educational BMPs should be considered from Menu B.

Table 3-1 lists public education BMPs.

\section{Industry}

Since most field studies have shown that industrial areas tend to be associated with high concentrations of pollutants in urban runoff, an effort should be made to help reduce the concentration of pollutants from industrial areas. However, in order to comply with federal and state regulations, certain industrial facilities are required to prepare their own sitespecific Storm Water Pollution Prevention Plans (SWPPPs). These plans identify potential sources of storm water pollution at the facility and prescribe a series of control measures. It is likely that the Regional Water Quality Control Board will not soon be able to review all the industrial SWPPPs. As a result, the cities should implement a local program to periodically check SWPPP implementation at industrial facilities in their respective jurisdictions, as described in Table 3-2. By doing so, the cities would become familiar with industrial facility operations and may be able to avoid implementing redundant BMPs on an area-wide basis, and help ensure that the cities' storm water permit provisions are not violated because of improper discharges from industrial sites. These BMPs do not require official facility audits", only to assure that SWPPPs have been developed and updated. Facility audits can be considered under Menu B.

\section{Illicit Discharges and Illegal_ Dumping}

Elimination of illicit discharges and illegal dumping are important elements of storm water pollution control. Illicit discharges are physical connections that inappropriately convey and direct non-storm water flows (that should go to the sanitary sewer) to the storm drain system. Illicit discharges can originate from virtually anywhere. In industrial and commercial areas, illicit connections are a major concern, and industries are required by Federal and State storm water regulations to eliminate them. Older sewered areas, which originally had on-site treatment systems (e.g., septic tanks) may have illicit connections to the stormdrains.

Illegal dumping is the disposal of liquids or other debris into the streets, gutters, storm drain inlets, or other locations where they can wash into the storm drain system. Pollutants resulting from poor housekeeping practices, however, can also be a significant source of illegal dumping in industrial, commercial, and residential areas.

Table 3-3 identifies BMPs which address inspections, recycling programs, public education, and field screening. Recycling/disposal programs should be concentrated in residential and commercial areas. These areas may currently have the fewest programs for recycling hazardous materials. The inspection BMPs focus efforts in industrial and commercial areas.

The BMPs on Menu A should be the elements of a comprehensive illicit discharge detection and elimination program. Failure to include "below-ground" inspections or "aboveground" inspections would likely result in failure to meet regulatory requirements. Thus, at a minimum, it is mandatory that either the "below-ground" and/or the "above ground" inspections be implemented. 


\section{Construction and New Development}

To comply with federal and state regulations, construction sites larger a specific size (generally greater than 5 acres) are required to prepare a Storm Water Pollution Prevention Plan (SWPPP). This plan identifies potential sources of storm water pollution at the site and prescribes a series of BMPs to control that pollution. When identifying sources the SWPPP should contain a detailed list of materials and wastes with storage/access areas, loading and unloading plans and a site map showing proposed storm water discharge locations. The Program should develop a standardized guidance manual for the construction industry and develop guidelines for checking SWPPP for the building permit plan checkers. Similar guidance for new development control measures should be developed for plan checkers. Table 3-4 identifies the BMP that address construction and new development.

\subsection{Menu B BMPs}

Several excellent BMPs were not chosen as part of Menu A despite their merits. Although these BMPs were not chosen as Menu A BMPs (because their local applicability is yet to be confirmed), they may be very effective at reducing pollutants entering Santa Monica Bay. In fact, many of the Menu B BMPs, listed in table 3-5, should be part of a comprehensive plan to reduce pollutants due to storm water discharges. In some cases, BMPs were left in Menu B because a number of them could be used to address a certain pollutants or a specific problem, however only one or two might be needed. Therefore, the Menu B BMPs are recommended but should first be screened to determine their appropriateness. The recommended BMPs are listed in Table 3-5.

In order to help the various cities decide which of the Menu B BMPs should be implemented, a formal decision-making process has been developed. The process involves using a matrix to allow the cities to apply a series of evaluation factors to the candidate BMPs to assess their usefulness. The factors and scoring methodology are described below. The factors should be used to determine if a BMP is appropriate for implementation in a particular city. The BMPs are to be rated using a simple plus or minus scoring system. After rating each candidate BMP relative to all of the factors, the sum total of all the pluses can be used to assign an overall score to each BMP.

\subsubsection{Possible Factors for Selecting Appropriate BMPs}

\section{Environmenta_ Implications}

This factor pertains to the potential environmental impacts or benefits which might be derived from the use of a candidate BMP. Although most BMPs have largely positive environmental implications, the development and operation of some of the larger-scale treatment-based controls and some maintenance-type controls could have adverse environmental consequences which warrant consideration.

Scoring: $\quad+\quad$ Implementation of the BMP will have more positive environmental impacts (i.e., enhances natural resources, wildlife and/or water quality) than negative impacts.

Implementation of the BMP could have more negative than positive environmental impacts. For example, installation of a BMP which 
Table 3-5: Menu B CANDIDATE BMPS

(organized by function)

Land-Use

Pollutants Addressed

\section{CANDIDATE "SOURCE CONTROLS"}

Control the Use and Disposal of Ferilizers. Pesticides, and Herbicides

a. Review current certification procedures/requirements for high volume users (e.g. commercial applicators, public agency personnel) and make recommendations for expanding the requirements to better address storm water quality impacts, as necessary.

b. Restrict use of fertilizers, pesticides, and herbicides (e.g., regulate the sale of household pesticide/fertilizer products).

c. Encourage the manufacturers \& distributors of pesticides, herbicides, and fertilizers to educate the public about the proper use and management of the products.

d. In cooperation with State Dept. of Agriculture and SCS, develop maps of appropriate fertilizer types and appropriate rates and combine with educational program.

e. Establish planting/andscape requirements for various districts and for land uses which encourage use of vegetation, either indigenous or imported that are self sustainable without

the need for human applications of fertilizers, pesticides or herbicides.

f. Develop a program to educate architects, landscape architects and engineers about storm water friendly design practices to reduce the need for fertilizers, herbicides and pesticides.

g. Collect additional samples for pesticide/herbicide analyses and try to define problem better.

h. Review current educ. programs related to low vol. use of pesticides/herbicides/fertilizers (e.g., household use) \& make recommendations for supplementing the pgms. with education re: storm water quality impacts \& use of non-polluting alternate products. i. Evaluate existing O\&M (and/or landscape mgmt.) programs for public right-of-ways and public drainage channels and ensure
that these programs limit the discharge of pollutants from pesticides/herbicides/fertilizers in nunoff.

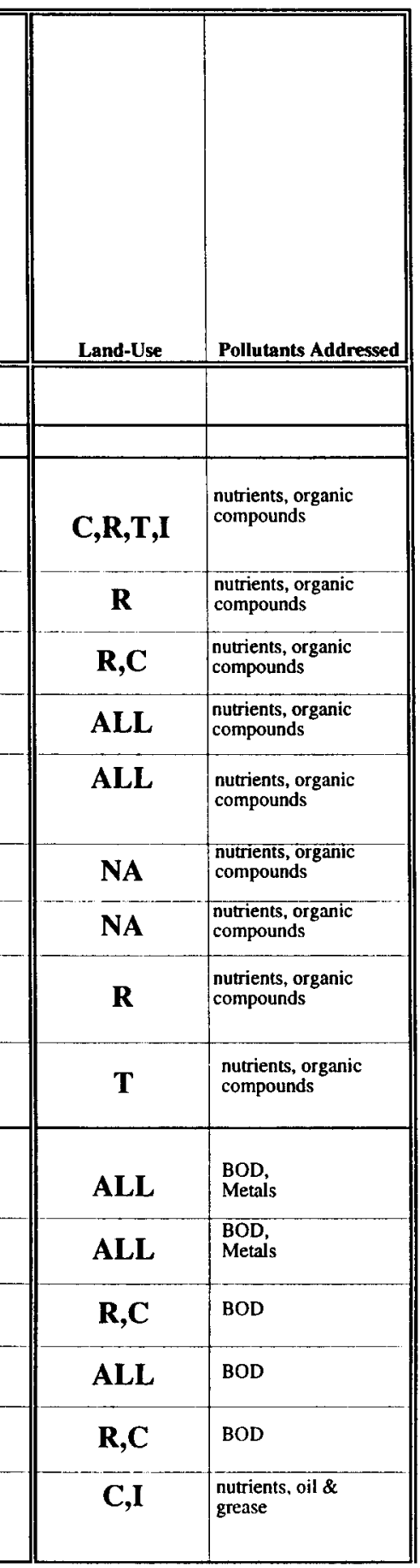

\section{Control Littering and Improper Waste Disposal Practices}

a. Continue to educate the public re: the storm water pollution impacts that result from littering practices.

b Strengthen enforcement of existing regulations which provide legal authority to control littering.

c. Work with citizen action programs to facilitate efforts to reduce littering (e.g, provide litter bags for use in cars).

d. Develop a comprehensive solid waste management program to reduce, recycle and control trash and yard debris.

e. Continue to provide, collect, and maintain more litter receptacles in strategic public areas, and during major public events. Expand programs as appropriate.

f. Educate owners and operators of trucks about the impacts of leaks, spills, and other releases from bulk materials during transportation (pollution effects of materials that are spilled onto roadways or other open space being washed into storm drains or waterways. 
Table 3-5: Menu B CANDIDATE BMPS

(organized by function)

Land-Use

Pollutants Addressed

g. Promote public involvement in "Keep Watershed Clean" campaigns in "adopt-a-creek" programs for specific waterways.

h. Support public involvement on such issues as transportation, planning, recycling, packaging control, etc.

i. Strengthen enforcement of existing regulations and programs regarding spill prevention and response. The objective is to eliminate spills of contaminants onto roadways or open spaces. where they may be washed into storm drains or waterways.

j. Develop and implement a program to ensure that municipal trucks hauling bulk materials do not leak, spill, or otherwise release contaminants onto roadways or open spaces, where they may be

washed into storm drains or waterways. Consider educational activities as appropriate.

k. Develop a program to encourage businesses (such as auto supply outlets and service stations) to provide collection services for used automobile fluids. Regulate to ensure appropriate disposal.

3. Prevent the Dumping of Pollutants inte Storm Sewers and Drainage Channels

a. Expand programs which provide convenient means for people to properly dispose of oil, antifreeze, pesticides, herbicides, paints, solvents, and other potentially harmful chemicals, and waste materials (recycle if possible).

b. Coordinate with EPA/DEQ to be sure that all potential water quality impacts are adequately considered at the time NPDES permits are issued for any discharges to storm sewers or

drainage channels. Include monitoring of all pertinent constituents as a permit stipulation.

4 Concrol Oil and Grease

a. Educate commercial/industrial sector re: the effective use of "housekeeping" practices, and oil/grease traps. Include the use of absorbents, cleaning compounds, oil/grease traps, and

other techniques for controlling oil and grease in gas stations, automotive repair shops, parking areas, commercial/industrial facilities, and food service facilities.

b. Educate the public to detect and repair vehicle nituid leaks.

c. Research, strengthen (if necessary), and enforce regulations which give local jurisdictions the authority to require oil and grease controls in areas which are significant sources (e.g., gas

stations, automotive shops, commercial/industrial facilities, parking areas, food service establishments).

d. Develop technical guidance which will facilitate compliance with regulations requiring oil and grease controls (e.g., oil/grease traps, plate separators, synthetic absorbent media, grassy swales) for indus./commercial facilities.

e. Develop and implement maintenance programs for oil/water separators where they do not exist. Insure maintenance of existing separators.

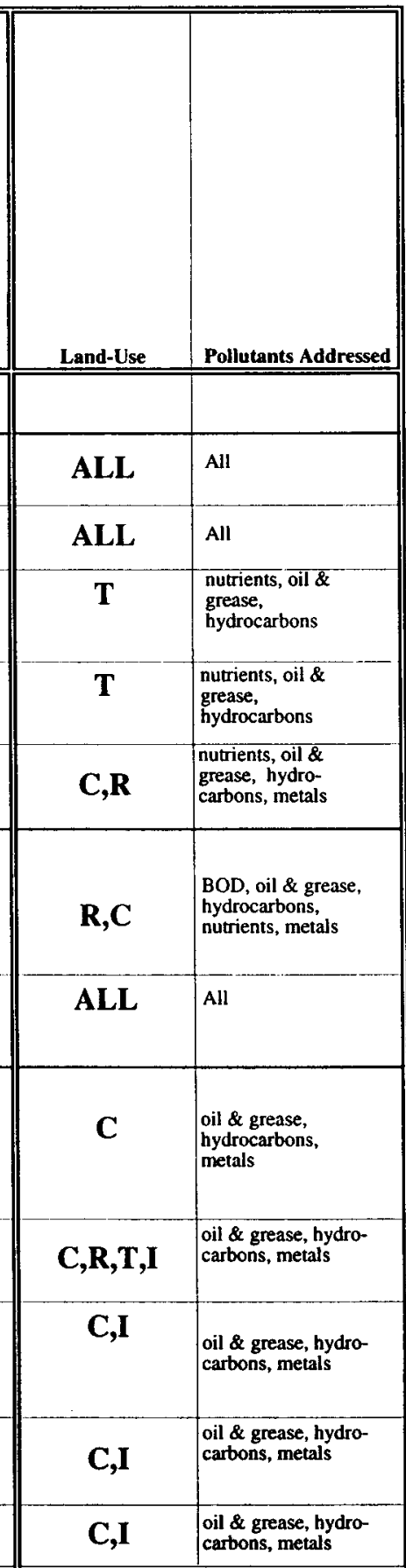


Table 3-5: Menu B CANDIDATE BMPS

(organized by function)

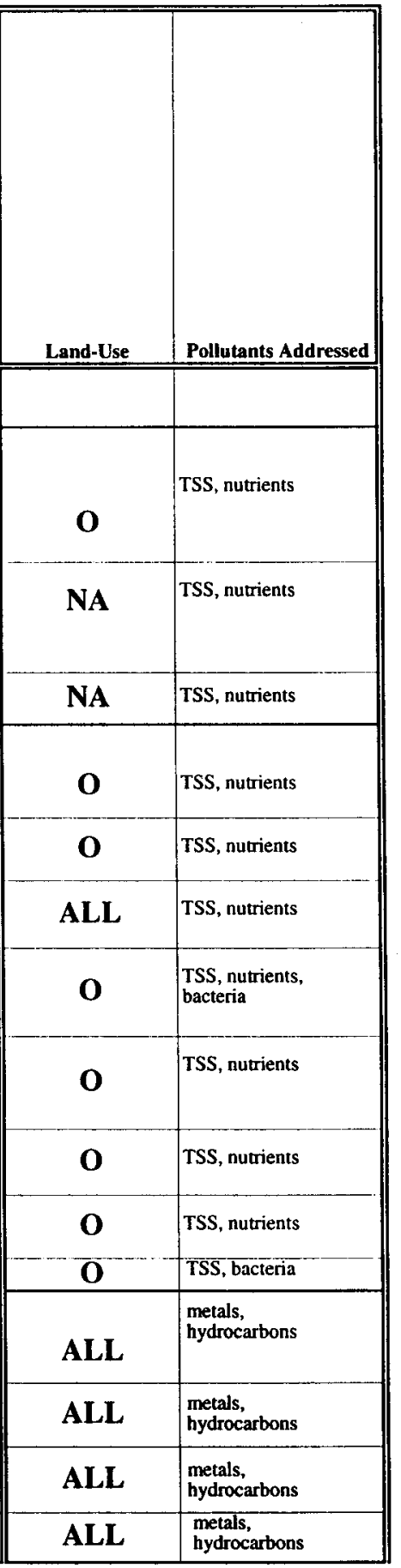


Table 3-5: Menu B CANDIDATE BMPS

(organized by function)

Land-Use

Pollutants Addressed

Cooperate with public transportation agencies, public agency motorpools, and/or public works deparments to provide effective equipment, and/or to use alternative clean-burning fuels where possible

f. Coordinate with the State's program to control and minimize atmospheric emissions associated with fireplaces and woodburning stoves, and to educate the public about the regulations.

8 Intensify the Maintenance/Repair of Storm Water Drainage System

Develop O\&M plan (or review \& revise as appropriate, existing O\&M plan) for all public storm water facilities (new \& existing). Incorporate evaluation of effectiveness into the O\&M plan. Provide a means of recording the observation of field

maintenance personnel, and transferring this information to the appropriate dept./agency, so the information can be used to locate and eliminate the source(s) of pollutants.

b. Require $O \& M$ plans for storm water facilities related to new privale development.

c. Develop and implement an aggressive field program to search for, test, remove, and properly dispose of sediment deposits (in drainage channels, streams and storm water storage/retention basins) containing relatively high concentrations of pollutants.

d. Det. effectiveness of increasing freq of cleaning out inlets, catchbasins, storm sewers, pump stations, channels, \& sw retention basins in areas where sediment \&/or debris tend to accumulate. Implement improved pgms where approp. (private facilities)

e. Research methods of economically and safely detoxifying high concentrations of pollutants at locations where they accumulate, i.e. detention basins, drainage chan ands, Current information on bio-remediation and solar detoxification may offer some solutions to the disposal of wastes issue.

f. Keep up to date inventories and maps of the storm sewer system

9 Improve the Maintenance of Major Paved Areas

a. Develop and implement intensified street sweeping programs in strategic locations (e.g., central business districts, shopping malls, major parking lots, industrial areas) and/or at strategic times (e.g., following extended periods of dry weather).

b. Determine the effectiveness of using street flushers to reduce pollutants in runoff.

c. Improve street sweeping on a watershed-wide basis (e.g., sweep more areas, more frequently)

d. Provide incentives to property owners to optimize street sweeping of private parking lot and other paved private areas (intensify as appropriate for selected locations.

e. Continue and expand pavement repair and maintenance on streets and parking areas (e.g., fill potholes, seal cracks, apply surface treatments) through a computerized pavement management system to reduce pollutants discharged to the storm drain system.

f. Evaluate ways that transportation authorities can reduce pollutant discharges associated with their maintenance and road rehabilitation operations.

\begin{tabular}{|c|l|}
\hline C,R,I,T & $\begin{array}{l}\text { metals, } \\
\text { hydrocarbons }\end{array}$ \\
\hline R & $\begin{array}{l}\text { metals, } \\
\text { hydrocarbons }\end{array}$ \\
\hline NA & \\
\hline C,R,I & All \\
\hline NA & All \\
\hline NA & All \\
\hline NA & All \\
\hline C,I & All \\
\hline NA & All \\
\hline ALL & All \\
\hline NA & All \\
\hline NA & All \\
\hline All \\
\hline NA
\end{tabular}


Table 3-5: Menu B CANDIDATE BMPS

(organized by function)

Land-Use

Pollutants Addressed

10 Prevent Rainfall and Runeff from Contacting Potential Contaminants

Educate re: the need to keep rainfall and runoff from contacting potential contaminants. Describe typical examples of the problem and practical solutions.

b. Develop and implement regulations which require landowners and/or tenants to provide covers (e.g., roofs, tarps) to keep rain off of areas which contain contaminants (e.g. chemical storage areas, waste storage areas, contaminated industrial areas), and keep runoff from draining through areas which contain contaminants.

c. Develop and implement an aggressive field program to search for, detect, and correct situations where rainfall and/or runoff presently contact potential contaminants.

11 Other Source Controls for Industries/Commercial Facilities

a. Develop and enforce requirements (e.g., structural controls, BMPs, connection requirements, development and redevelopment practices) for existing and developing industries and commercial establishments.

\section{CANDIDATE "HYDRAULIC CONTROLS"}

Reduce the Volume of Roof Runoff which Enters Storm Sewers

Educate re: the need to minimize the total roof drain runoff volume contributing directly to both storm sewers and drainage channels. Describe basic principles and suggest practical alternatives to minimize their peak rate of discharge.

b. Research, strengthen, implement, and enforce regs providing legal authority to prohibit new direct connections (roof drains to storm system) \& which require retrofitting existing bldgs, where practical.

c. Provide education and guidance encouraging architects, engineers, and building departments to implement systems which temporarily retain rainfall peaks on rooftops and/or in retention facilities, minimizing the peak rate of discharge to the storm

system or drainage channels.

d. Create incentives and make institutional changes to encourage that roof drains not be connected directly to the storm drainage system.

Enhance Sufface Retention and Infiliration

Educate re: the need to minimize the total volume of runoff and the peak rate of runoff from a given area. Describe basic principles and suggest practical alternative means to enhance surface retention and infiltration.

b. Research, strengthen (if necessary), implement, and enforce regulations which give jurisdictions the legal authority to require site drainage designs and systems which minimize the total volume of runoff and the peak rate

of runoff from new construction, where local conditions permit.

c. Require new commercial, industrial, institutional, and major multi-family residential building complexes to have drainage facilities that incorporate on-site retention and/or infiltration, to assure that neither the total volume

of runoff nor the peak rate of discharge to the storm sewer system or drainage channels are increased.

\begin{tabular}{||c|l||}
\hline & \\
Land-Use & Pollutants Addressed \\
\hline ALL & All \\
\hline $\mathbf{I , C}$ & All \\
\hline $\mathbf{I , C}$ & All \\
\hline $\mathbf{I , C}$ & All \\
\hline C,I,R & All \\
\hline C,I,R & All \\
\hline C,I & All \\
\hline C,I,R & All \\
\hline C,I,R & All \\
\hline C,I & All \\
\hline C,I,R,T & All \\
\hline
\end{tabular}


Table 3-5: Menu B CANDIDATE BMPS

(organized by function)

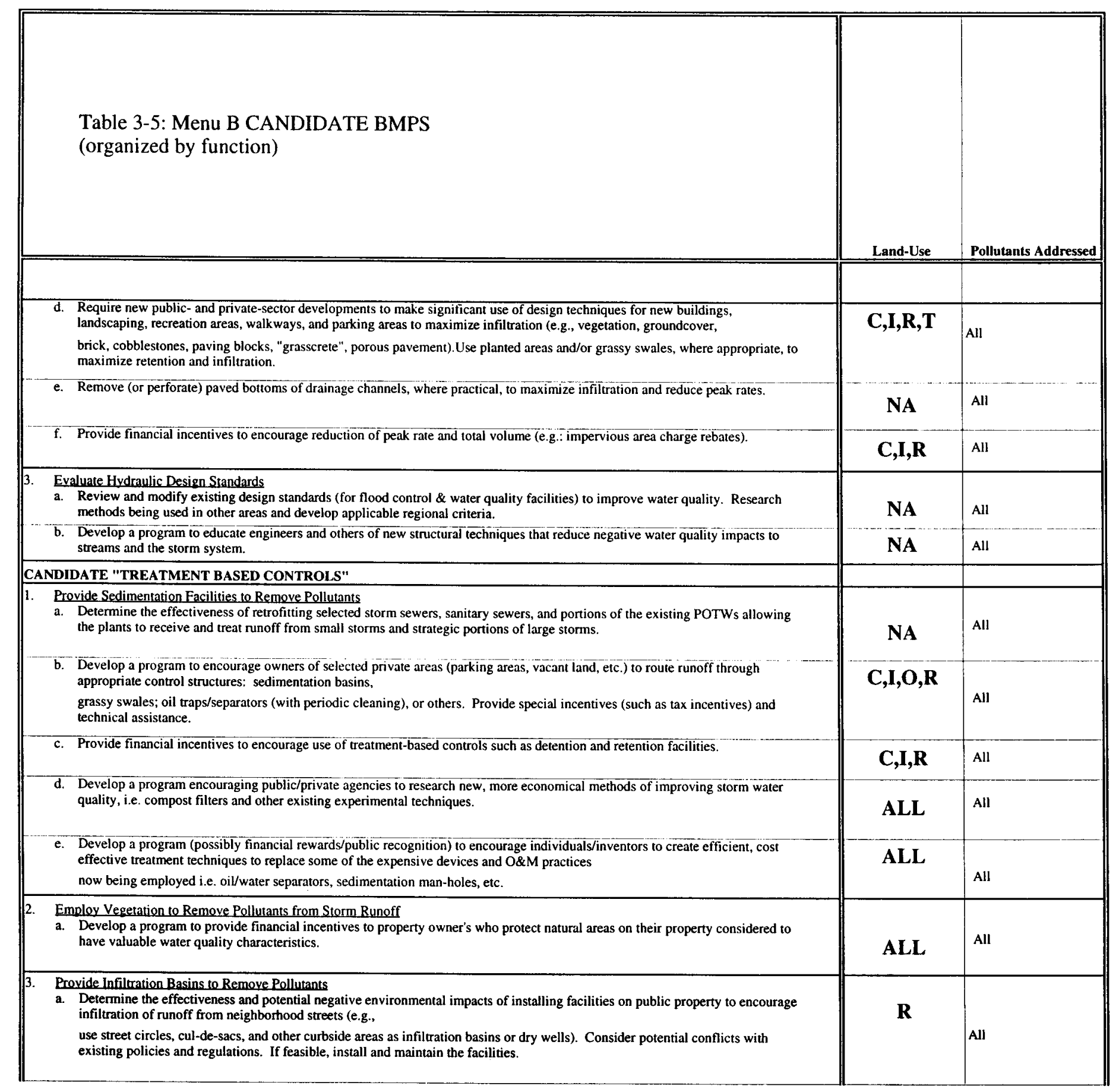




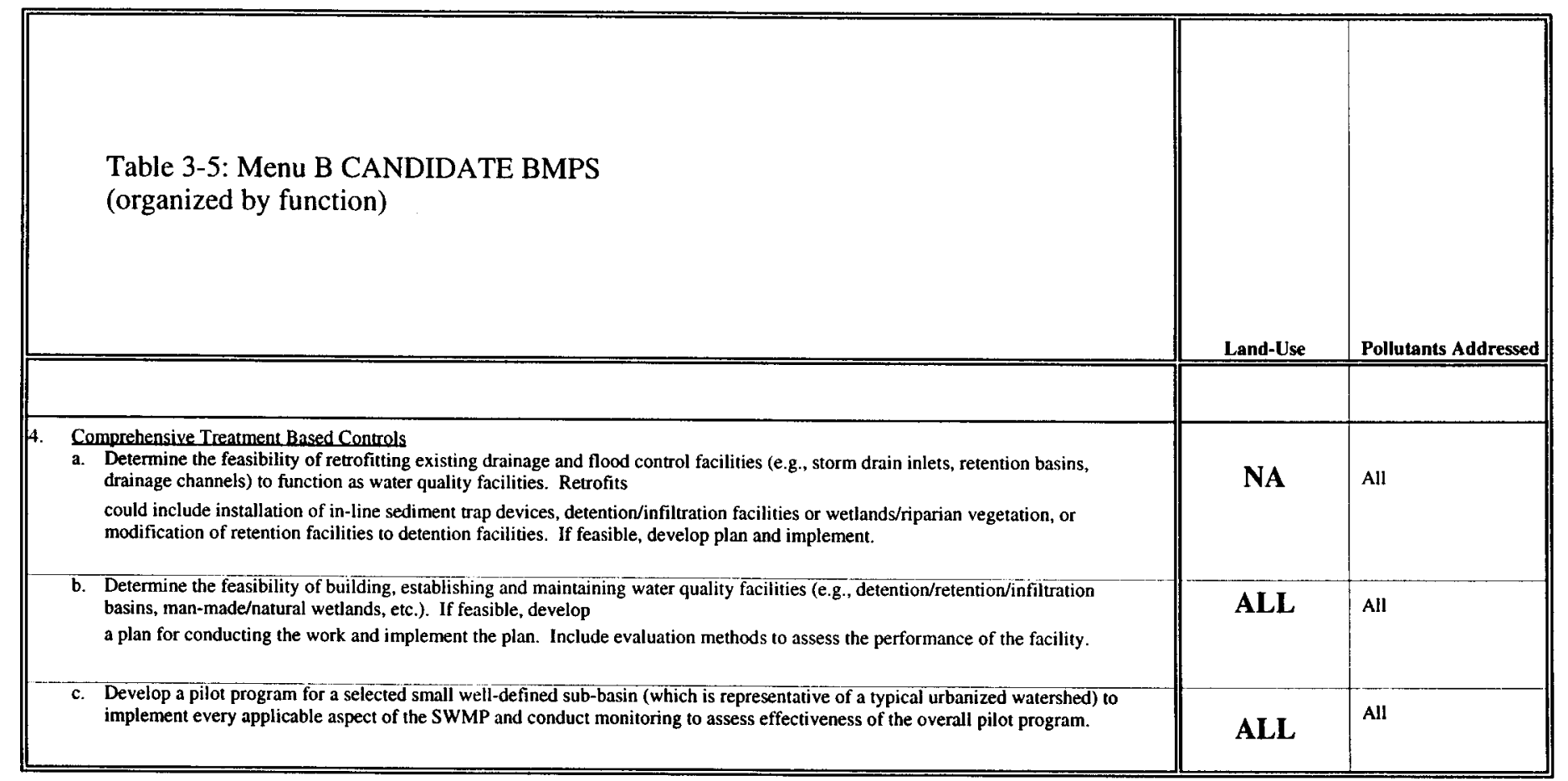


improves water quality could contribute to flooding problems (and impairment of natural resources) if not maintained properly

\section{Effectiveness Regarding Pollutants of Concern}

This factor refers to the candidate BMPs ability to afford a reasonable increment of control for the targeted pollutants (i.e., those pollutants that have been designated as being the focus of this storm water quality program - see discussion of pollutants in Section 2.5). It is recognized that each storm water BMP, taken independently, might not have much effect on the overall storm water pollutant loading problem. However, it is intended that each selected BMP should contribute enough toward the overall program to warrant its inclusion.

Scoring: $\quad+\quad$ The BMP is expected to control the pollutants of concern identified for Santa Monica Bay.

- The BMP is not expected to control any of the pollutants of concern to a significant extent.

\section{Implementing_Agency/Department_Acceptability}

This factor pertains to how readily various public agencies and/or city departments (i.e., the storm water dischargers, not the regulatory agencies) would accept the measure and implement it properly. In many cases, implementing agencies/departments are more likely to accept a candidate BMP if its implementation would help them meet some other objective and/or if the BMP is an extension of some other program that is already in place or is expected to be implemented.

Scoring: $\quad+\quad$ The various implementing agencies and departments would readily accept the BMP and could incorporate it into their existing programs and tasks to accomplish multiple objectives.

- $\quad$ The BMP would not be readily accepted and implemented by the various agencies and departments.

\section{Regulatory Requirements}

This factor refers to the candidate BMPs consistency with present and anticipated regulatory requirements. For example, the EPA is presently developing programs and policies which will require the implementation of certain storm water control measures. Candidate control measures that are likely to be required by these or other federal, state, and/or regional regulatory actions should probably be given higher priority (if they appear to be generally cost-effective) in both the screening and the selection process.

Scoring: $\quad+\quad$ The BMP meets the intent of the NPDES storm water requirements for Storm Water Management Programs.

- The BMP does not meet the intent of the NPDES storm water requirements for Storm Water Management Programs. 


\section{Public Acceptance}

This factor refers to how readily the public would likely accept the BMP. Such evaluations are clearly subjective and depend heavily upon the segment of the "public" that is likely to be most affected, and that public's knowledge, understanding, and attitudes regarding the candidate BMP and its purpose. This latter factor can often be influenced by focused education and public information programs.

Scoring: $\quad+\quad$ The public would readily understand and accept the BMP and participate (to the extent necessary/possible) in ensuring successful implementation.

- $\quad$ The BMP would not be readily understood and accepted by the public.

\section{Risk/Liability}

This factor pertains the risks or liabilities which might accompany implementation of a candidate BMP. In some cases, the problems (e.g., legal, political, institutional, insurance) associated with risk and/or liability might well be more important than their cost or their effectiveness in controlling storm water pollution problems.

Scoring: $\quad+\quad$ Implementation of the BMP includes a minimal amount of risk and liability.

- Implementation of the BMP could generate a high level of liability for the implementing agency/individual (e.g., an unfenced detention facility in a residential area could be a hazard to small neighborhood children).

\section{Equitability}

This factor pertains to the degree to which the candidate BMPs associated costs and resultant benefits would be considered generally equitable. The issue here is one of fairness. In some cases, it may be necessary (or at least expedient) to implement a BMP which is considered to be inequitable (i.e., the party who will pay for the control is not the party who caused the problem and/or will not receive the benefit of the control). Such cases can be avoided by evaluating candidate BMPs relative to this factor.

Scoring: $\quad+\quad$ The BMP is equitable in terms of costs and benefits--costs are borne by those who are responsible for the pollution problem and/or those who benefit from the BMP.

- $\quad$ Those who pay for implementation of the BMP are not responsible for the problem and/or receive little or no benefit.

\section{Reliability}

This factor refers to the candidate BMPs ability to function, if properly implemented, in a predictable manner to effectively control pollutants. This is an important consideration as some controls are not very effective during sizable storm runoff events and/or are unpredictable in terms of their performance. 
Scoring: $\quad+\quad$ It is highly likely that the BMP will control pollutants as it was designed to, or is expected to (as long as it is implemented and maintained properly).

- $\quad$ It is difficult to accurately predict how effective the BMP will be at controlling pollutants.

\section{Sustainability}

This factor refers to the candidate BMPs likelihood of being properly implemented over a long period of time after its initial introduction, and the likelihood that the BMP will continue to be effective over a long period of time. This is an important consideration for those BMPs whose effective performance depends on education, volunteer efforts, and/or the consciousness and cooperation of the public.

Scoring: $\quad+\quad$ It is highly likely that the BMP will be effective at controlling pollutants over a long period of time.

- $\quad$ It is less likely that the BMP could be effective over a long period of time.

\section{Universality}

This factor refers to the degree to which implementation of the candidate BMP would be practical only if achieved on a very large geographic scale. For example, the lead content of urban runoff has diminished significantly, probably in response to a decade of concerted regulatory requirements and technical actions to reduce the lead content of gasoline, paint, and other products on a nationwide scale. Similar large-scale actions may be capable of reducing other storm water pollutants. Candidate BMPs need to be evaluated in this instance in terms of how universally they would have to be applied to achieve significant benefits. This can be an important consideration, because it can have significant cost, schedule, and legal/political/institutional implications.

Scoring: $\quad+\quad$ This BMP would be effective at controlling pollutants regardless of how extensively it is implemented in the Santa Monica Bay area.

In order to be effective, it will be necessary to implement this BMP in every basin of the Santa Monica Bay Metro area.

\section{Implementation Costs}

This factor refers to the approximate magnitude of the various costs involved in the initial implementation of a candidate BMP. The cost elements to consider may vary significantly for each BMP. Implementation costs considered here include such one-time cost items as planning, design, land acquisition, construction, and equipment acquisition.

Scoring: $\quad+\quad$ It would be relatively inexpensive to initiate implementation of the BMP.

- $\quad$ The initial cost of implementing the BMP is expected to be fairly expensive. 


\section{Operational Costs}

This factor refers to the approximate magnitude of the various costs associated with operations, maintenance, repair, support services, and periodic equipment replacement (where applicable). For some BMPs, this would include labor, electric power, fuel, replacement parts, monitoring programs, laboratory services, consulting services, legal services, and other continuing costs.

Scoring: $\quad+\quad$ The continued cost of implementing/maintaining the BMP over time is expected to be inexpensive.

- The continued cost of implementing/maintaining the BMP over time is expected to be fairly expensive.

\section{Elexibility for Phased Implementation}

This factor refers to whether or not the BMP can easily be phased for implementation over the 5-year term of the NPDES permit.

Scoring: + It would be easy and possible to phase this BMP for gradual implementation over the life of the permit. For example, the BMP could be implemented in a pilot or demonstration study first, followed by full-scale implementation if the pilot test is successful.

- In order to be effective, the BMP would have to be implemented initially and continuously at a full-scale rate.

\section{Ability to Demonstrate Compliance}

It will be necessary to demonstrate the program's success and compliance with the NPDES permit by documenting tasks which have been accomplished and by evaluating the effectiveness of the BMPs when possible. In selecting BMPs, it is important to consider the ease of demonstrating compliance, either qualitatively or quantitatively.

Scoring: $\quad+\quad$ It would be easy to demonstrate to the RWQCB and other regulatory agencies that the BMP is effective at meeting the goals and objectives of the NPDES requirements (i.e., improving storm water quality).

- It would be time consuming or expensive to demonstrate compliance and assess the effectiveness of the BMP either quantitatively or qualitatively.

\subsection{MENU C BMPS}

Menu C BMPs are BMPs that may help reduce storm water pollution in an indirect way or for a specific circumstance. Table 3- 6 lists the Menu C BMPs. These BMPs can be implemented if the circumstances for implementation are correct. For example, Menu C BMPs 3a, b are directed at controlling leaks from storage tanks. There are already regulatory requirements regarding tank leaks. Therefore, this BMP is only important if there is concern that the other regulations are not sufficient. Another example is Menu C 
TABLE 3-6: MENU C CANDIDATE BMPS

(organized by function)

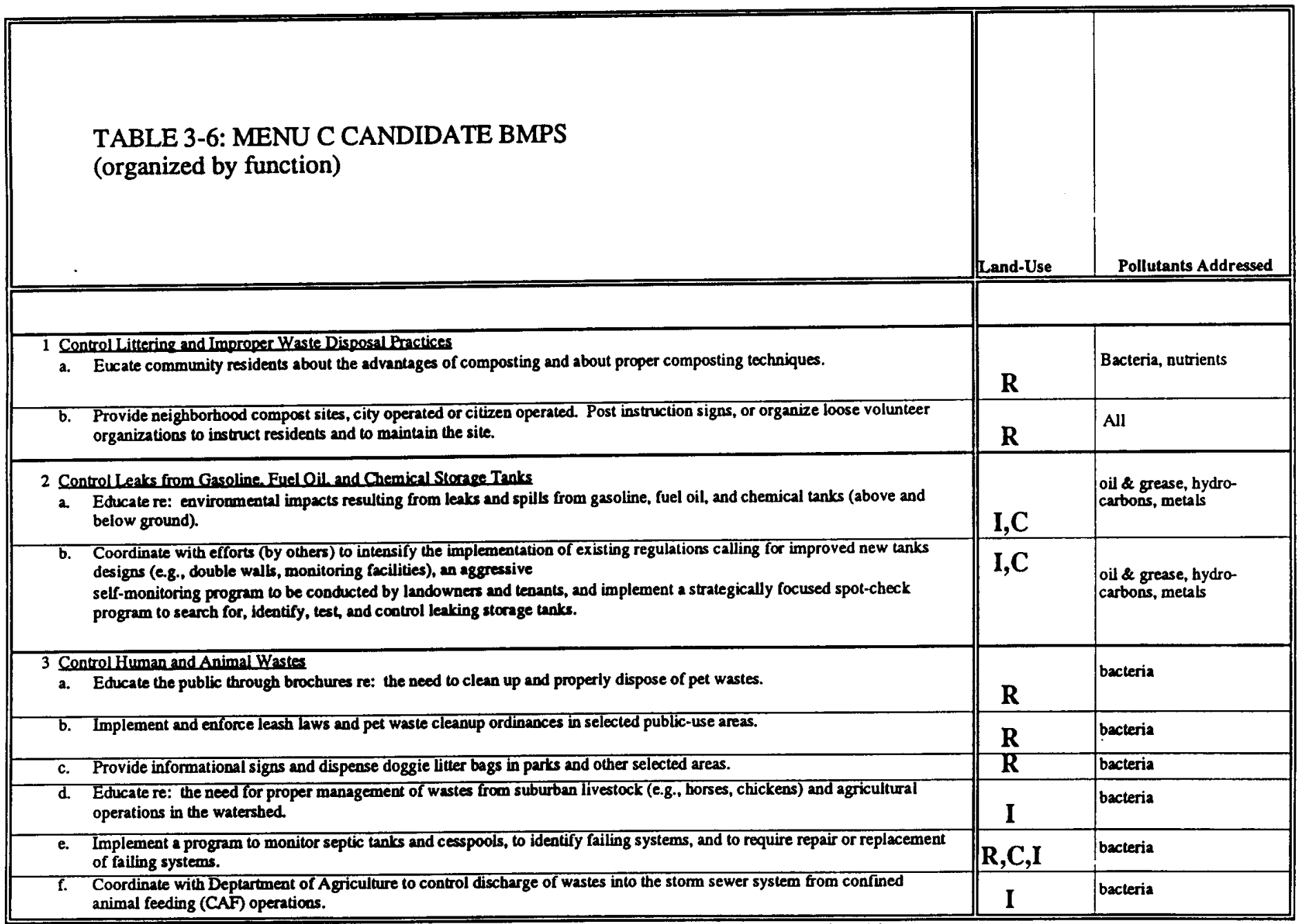

C - Commercial, R - Residential, T - Transportation, I - Industrial, O - Open, NA - Not

Apolicable 
BMPs 4 a-f. These BMPs only need to be implemented if high levels of bacteria and fecal coliforms are found in storm water.

\subsection{THE SCREENING PROCESS AND DEVELOPMENT OF THE BMP PLAN}

The above sections present the tools necessary to conduct a BMP selection process utilizing a methodical approach. This approach takes into account factors that should be utilized to select a defensible set of BMPs for implementation. Section 2.5 presented a brief discussion of water quality parameters of concern and land-use considerations that should be consulted when evaluating the factor "Effectiveness regarding pollutants of concern." When evaluating the BMPs most agencies that we have worked with in the past have chosen to convene a number of individuals from the affected departments within the agencies and have each of them participate in workshops to set-up and define the water quality problems and define the BMP selection process.

There are a number of ways that co-permittees could proceed with an evaluation and selection of appropriate BMPs. Each co-permittee could evaluate the BMPs separately, with their own decision makers, and then come together to discuss and decide which BMPs should be implemented watershed wide. Or alternatively, the co-permittees could conduct the screening process as a group and then evaluate which BMPs they should consider for their areas. For many of the BMPs, it would probably make the most sense to implement them basin-wide by an overall program manager (i.e., Los Angeles County), while others may need to be implemented basin-wide but by each co-permittee, and still others will be implemented individually and not basin-wide.

In screening evaluations conducted in Eugene and Portland, another approach was to screen the selection factors first. The decision makers sometimes chose to combine factors (e.g. Implementation Costs and Operational Costs into just Costs) or to select the top 5 or 6 factors which they felt were the most important to selecting the BMPs. After this was completed, some also chose to weight the scores for 2 or 3 of the 5 or 6 factors which received the most votes as important selection factors. Those that were weighted higher received higher scores for each positive vote. Finally, in some of the evaluations, the factors were not just evaluated as either positive $(+)$ or negative $(-)$, but a neutral rating was also established. When this was done, summed negative ratings were subtracted from summed positive ratings to achieve a factor score from the group scoring the BMP. Then the weighting was applied to the factor score, before the total score was recorded and combined with other factor scores.

Once the rating and scoring procedures are decided upon and completed, co-permittees will then have a list of BMPs with overall scores. The next step is to then decide at what score should BMPs be implemented. It is our opinion and experience that co-permittees should not try to implement too many BMPs at one time. Our approach in Portland was to develop a histogram plot of the scores and to look for a break point in the histogram. This occurred at about 35 control measures. We felt that this was reasonable number of BMPs to consider implementing over a 5-year period; especially when one considers that many of the BMPs can be combined into more comprehensive BMPs, such as having one public education program which targets the individual education BMPs selected for implementation. The scores of the BMPs selected for implementation can also be used to guide the priority for implementation.

Once the BMPs are selected, detailed descriptions of the BMPs should be prepared. The descriptions should include a more detailed description of the BMP, identification of the 
staff that will be responsible for implementing the BMP (including getting it started and maintaining it), the funding requirements, schedule for implementation and ongoing activities (i.e., catch basin cleaning frequency), and how the implementation of the BMP will be documented and evaluated. These descriptions should be either prepared by the implementing departments within the perimeter's agency or at least circulated within that department for comments and input. Once the BMP descriptions are prepared and compiled, the co-permittee agency should seek and document approvals and commitments by the managers of the co-permittee agency to implement and/or support the implementation by others (i.e., Los Angles County for watershed-wide measures) of BMPs. 
This document has recommended a list of BMPs that should be implemented now, and a list of BMPs that should be carefully considered for implementation either now or during the next several years. The BMPs recommended in Section 3 are ones that are considered to be a base set of BMPs that should be completed as a part of an overall storm drainage quality management plan and be implemented basin-wide.

In this document, we have also described a method for carefully evaluating and selecting BMPs from a second list (Menu B). It is expected that a number of these measures should be implemented as a part of an overall storm drainage pollution management plan. However, each agency and City should carefully consider each of these measures in relation to their own identified problems and constraints. It is likely that some of these measures would be implemented by only some of the agencies or Cities in the watershed, while others may be implemented watershed-wide. We believe that agencies and Cities should evaluate this list and make selection of BMPs from the list (or any added BMPs) within 6 months. Implementation of the measures should be based upon prioritizing the BMPs for implementation during the screening process.

Participating agencies and Cities should carefully monitor the implementation of BMPs and monitor their effectiveness. Monitoring for effectiveness does not imply that water quality testing needs to be completed, but does imply that some measure be developed for each BMP to gage its effectiveness (i.e., public surveys for education campaign effectiveness, or keeping records on pounds of materials removed during street sweeping and catchbasin cleaning programs), and document that the BMP has been implemented. This "evidence" should be compiled in an annual report prepared by the County with regards to the County's NPDES permit with the Regional Board.

Finally, it is imperative that a carefully designed and implemented monitoring program be implemented. A suggested program was prepared as a part of this effort (Strecker and Stenstrom, 1993). The purpose of the program would be to better define the water quality characteristics of storm drainage discharges to Santa Monica Bay from various land-uses and overall loadings from large mixed drainages. This will enable Agencies and Cities to prioritize water quality problems and BMPs to address those problems in future management plans to be developed under the NPDES permit program. It will also begin to develop a base to which future water quality can be compared to. 
Eganhouse, R.P and I.R. Kaplan (1981). "Extractable Organic Matter in Urban Stormwater Runoff. 1. Transport Dynamics and Mass Emission Rates." Environmental Science and Technology, Vol 15, No. 3, pp 310-315.

Federal Highway Administration (1990). Pollutant Loadings and Impacts from Storm Water Runoff, Volume III: Analytical Investigation and Research Report. FHWARD-88-008, Turner-Fairbank Highway Research Center, 6300 Georgetown Pike, McLean, VA 221010-2296.

Gold, M., Bartlett, M., McGee, C., and G. Deets (1992). Pathogens and Indicators in Stormdrains within the Santa Monica Bay Watershed. A report to the Santa Monica Bay Restoration Project, 101 Centre Plaza Drive, Monterey Park, CA 91754-2156.

Green, Gerald E. (1992). Ozone Disinfection and Treatment of Urban Storm Drain DryWeather Flows: A Pilot Treatment Demonstration Project on the Kenter Canyon Storm Drain System. A report to the Santa Monica Bay Restoration Project, 101 Centre Plaza Drive, Monterey Park, CA 91754-2156.

MBC Applied Environmental Sciences (1988). The State of Santa Monica Bay: Part One: Assessment of Conditions and Pollution Impacts. A report prepared for the Southern California Association of Governments, $600 \mathrm{~S}$. Commonwealth Ave., Los Angeles, CA 90005.

Stenstrom, M.K., Silverman, G.S., and T. Bursztynsky (1984). "Oil and Grease in Urban Stormwaters." Journal of the Environmental Engineering Division, ASCE, Vol 110 , No. 1, pp 58-72.

Stenstrom, M.K. and E. W. Strecker (1993). Assessment of Storm Drain Sources of Contaminants to Santa Monica Bay: Volume I: Annual Pollutnats Loadings to Santa Monica Bay from Storm Water Runoff. A report to the Santa Monica Bay Restoration Project, 101 Centre Plaza Drive, Monterey Park, CA 91754-2156

Stenstrom, M.K. and E. W. Strecker (1993). Assessments of Strorm Drain Sources of Contaminants to Santa Monica Bay: Volume III: Surface Drainage Water Quality Monitoring Program Plan. A report to the Santa Monica Bay Restoration Project, 101 Centre Plaza Drive, Monterey Park, CA 91754-2156

US Environmental Protection Agency (1983). Final Report of the Nationwide Urban Runoff Program. Prepared by Woodward-Clyde Consultants for the Planning Division, US EPA, Washington, DC. 
The first parts of this report have described a consensus building procedure for selecting best management practices (BMPs) for Santa Monica Bay. It is an adaptation of a general procedure that is applicable to almost any watershed and should be used to develop the final set of BMPs for the Bay. In spite of our recommendation to follow this procedure, there are several BMPs that have been studied or discussed during the course of this project, which have high applicability to the Santa Monica Bay Watershed. The authors would like to present these BMPs for further consideration and to provide a reference to existing or previous activity associated with the BMP. Pervious experience with the BMPs within the Bay watershed should be helpful in the consensus building. Several other BMPs are also presented which may not be specific to the Bay, but have been discussed over the course of this project and deserve further consideration. It is hoped that this appendix will preserve the work done in developing and studying them, and that this information will be used in the previously described consensus building procedure.

The following BMPs are recommended. They are divided into two categories; the first category is for BMPs which can most likely be implemented with existing knowledge and do not require pilot studies or demonstration projects prior to implementation. The second category includes BMPs that probably require a demonstration project before wide scale implementation.

\subsection{BMPS SUITABLE FOR IMMEDIATE IMPLEMENTATION}

The following BMPs are recommended for further consideration and implementation in the Santa Monica Bay watershed. The authors believe that they can be implemented based on existing information, which includes experience from other areas as well as knowledge within the technical staff of the Santa Monica Bay Restoration Project, its contractors and technical advisory committee.

Public Education and Outreach Programs Public education is the key to managing many problems associated with urban runoff pollution. Public education programs are preventive in nature and therefore tend to be less expensive. It is always less expensive to prevent an urban runoff pollution problem than to treat it after it has occurred. Active public participation is required to mitigate many problems such as illegal dumping, littering and other undesirable practices. Therefore, education programs should have very high priority. Several programs are underway already within the watershed. This list is not inclusive and is meant to complement and/or note the public education programs currently being developed and implemented by the City and County of Los Angeles, as well as other cities within the Santa Monica Bay Watershed.

- A watershed-wide brochure on water quality protection and NPDES permit information could be developed and distributed to residents (see menu $A$ in the text of the report). An alternative is to develop a brochure that contains the basic education principles while leaving room for various cities and agencies to customize the brochure by including information about their specific programs 
or concerns. Masters of this alternative brochure could be distributed to cities and agencies for customization and publication.

- Construction is a large source of suspended solids that eventually become entrained in urban runoff. There are many construction techniques that can minimize suspended solids pollution. Education and training programs need to be developed to educate contractors and inspectors to insure that the appropriate building techniques are used. There are many Universities and Colleges in the Santa Monica Bay Watershed area that have extension programs and other education mechanisms that can be employed to provide this training. A local contractors organization (i.e. Association of General Contractors) could be utilized to help develop a manual or other educational materials describing proper erosion and pollution control practices at construction sites

- Automotive businesses are large potential sources of urban runoff pollution, especially for hydrocarbons and metals. Education programs including workshops, extension classes, and inclusions of new materials in existing automotive repair school curricula, are mechanism to educate businesses about practices to minimize urban runoff pollution.

- A "hot line" can be set up to allow citizen reports of urban pollution events. Its success would be directly related to the follow-up action (e.g., enforcement, clean-up) by appropriate agencies.

Public Participation Programs Programs to take advantage of volunteerism can be developed. Such programs could be used to clean up problem areas, stencil storm drains, post signs and foster other activities that reduce urban runoff pollution. Several issues must be addressed prior to implementation, such as safety of the volunteers and liability.

Storm Channel Cleaning Late in the dry season, Ballona Creek and other stormwater channels with dry weather flow are heavily covered with debris and algae rafts. These algae rafts are dense and anaerobic. A proposed BMP is to clean the Creek and other channels by removing the debris and rafts. The debris and algae can either be removed or reduced in magnitude. In this way "shock" loading to the Bay during the first heavy rainfall will be reduced.

If the proposed Ballona Creek treatment plant is constructed, it might be used in conjunction with the proposed cleaning program. In this case algae mats and sediment could be mobilized and pushed toward the plant. The plant, probably composed of physical processes such as screening and sedimentation and located at the old stormwater diversion facility on Ballona Creek, could be designed to remove grit (silt) and debris. Through such treatment the mass emissions of potential toxics adsorbed to the surface of particulate are reduced, and that trash collection on the beaches is minimized. Reduced debris has beneficial impact on marine life (e.g., avoidance of mammals swallowing clear plastic bags, etc.).

Erosion Control The Malibu Creek watershed, due to its size and steep slopes, contributes a large fraction of the particulates entering the Bay, and is largely open or undeveloped. To control particulates, construction codes that minimize erosion need to be implemented. Such codes and practices should be enforced through an active inspection program, which is particularly important during the rainy season. 
NPDES Enforcement After NPDES permits are required it will be difficult for the Water Quality Control Board to insure that all businesses required to obtain permits actually obtain them. To assist the Board, a database can be created from the tax assessor's databases, business code databases and SIC codes. This database can be compared to the Board's permit database and businesses not having permits can be reminded to obtain them. If they do not cooperate their non-compliance can be reported to the board for action.

Qil Recycling Oil recycling programs are still inadequate and more facilities that will accept used oil are needed. An ordinance requiring businesses selling more than a certain minimum amount of oil to accept used oil is one way of creating more recycling facilities. Also an ordinance restricting sales of oil at very small facilities (convenience stores) would force sales from to stores with recycling facilities.

Storm Drain Inlet Identification Stenciling storm drains to identify them and protect them from accidental contamination can be done County-wide. The experience in Santa Monica can be used as a model for the county-wide program. It should be possible to use volunteers or to use this as a public service activity.

Storm Drain Effluent Dispersion Many storm drains (e.g., Pico-Kenter) terminate upstream, far from the beach water line. These drains actually encourage human contact and should be extended to meet the surf line, or extended beyond the surf line if dilution is desired. In this way there will be less risk to beach goers. Pico-Kenter storm drain has been extended to provide this dilution and this experience can be used in the further evaluation and development of this BMP.

Street Sweeping and DisposaL Practices A county-wide approach to disposal practices of could be employed to insure street sweeping and certain basin materials are disposed properly and to minimize losses of debris during transportation. Street sweeping practices can be reviewed to ensure that maximum benefits are obtained.

Improved Highway Runoff Control Runoff from highways is usually 2 to 4 times greater in contaminant concentration than runoff from other land uses. Controlling pollution from this land use is potentially much more cost effective than controlling pollutants from other land uses such as single-family residential. Programs could be developed with $\mathrm{Cal}$ Trans and others responsible for street and highway maintenance to insure that new construction and retrofit projects use the best techniques for minimizing urban runoff pollution.

BMP Construction Manual A BMP construction manual could be developed with a general contractors' organization to further BMP construction technology. Several similar manuals have been developed for other areas or disciplines and may be adaptable for this use.

Illegal Dumping and Illicit Stormdrain Connection Existing techniques for regulating and monitoring dumping and sewer/stormdrain connections can be reviewed to 
insure that maximum benefits are obtained. A model inspection/investigation manual could be developed for county-wide use by appropriate agencies. The manual could provide specific details on procedures, health and safety requirements and inspection practices. The manual would serve to facilitate the early implementation of this important BMP.

\subsection{BMPS REQUIRING DEMOSTRATION PROJECTS BEFORE IMPLEMENTATION}

Porous Pavements Porous pavement parking lots need to be demonstrated to public agencies and consulting firms in order to evaluate and prove their effectiveness. Currently, many agencies believe that porous pavement parking lots are unmanageable, and this perception needs to be changed, or new techniques need to be developed. There are other practices potentially useful for parking lots that can be implemented. Parking areas have very high emission rates per unit area and their management is probably one of the more cost effective techniques for minimizing urban runoff pollution. Additionally, parking lots generate income that can recover the cost of the management.

Infiltration Areas Grassy swales (green belts) have been used with success in many areas but are not considered a proven technology in Los Angeles. One or more demonstration projects quantifying pollutant removals are recommended.

Vehicle Inspection Programs Smog inspection programs are largely ineffective for certain problem vehicles, which have high mass emissions and whose owners avoid the intent of the inspection by finding dishonest inspectors or defeating controls after an inspection. The gaseous emissions from vehicles contribute to urban runoff pollution as they settle on land or are rained out. It is estimated that the majority of pollutants from automobiles in Los Angeles are produced by older vehicles and it is very likely that automobiles are one of the greatest contributors to urban runoff pollution. Smog inspection programs have no requirements at present to control dripping or leaking vehicles.

It may be economically impractical to require leaks to be fixed, especially for older cars. Never the less, smog inspection programs can be improved; for example, there is a proposal to change the existing program of static inspections to moving vehicle inspections, or requiring independent inspectors who do not also perform repairs. Recent programs to remove old vehicles by allowing industries to purchase them to obtain air pollution credits should be encouraged since reduced hydrocarbon emissions in urban runoff will undoubtedly occur.

Stormdrain Water Disinfection Two recent studies (Green, 1992; Gold et al., 1993) have shown the presence of fecal contamination in stormdrains. An inspection program that can target illegal connections and leaks will help eliminate this problem. Indicator water quality parameters are required.

Detention Basins Detention basins are now a well-developed technology for stormwater pollution control. One or more demonstration projects are required to convince agencies and the public of their value in Los Angeles.

Stormwater Infiltration Dry weather flow constitutes the vast majority of urban runoff pollution during the April to September periods. Dry weather flow can be reduced 
by using infiltration zones in regions near stormdrains. For example, Ballona Creek could be equipped with a porous low flow channel to allow infiltration. Further study to determine the feasibility, amount and impacts of the infiltration are required.

Diversion of Dry Weather Flow to Sanitary Sewers Dry weather flow in particularly sensitive areas or areas without proper stormdrain termination (e.g., PicoKenter) could be diverted to sanitary sewers. This option has several advantages. Sanitary facilities usually have lower flow rates in the summer than in the winter, when sanitary sewer infiltration occurs. The reduced summer sanitary flow may provide capacity to allow several stormdrains to be diverted. In wet weather the diversion can be terminated by automatic monitoring equipment. The demonstration project at Pico-Kenter is a good example of this practice and should be further investigated and developed to allow its more widespread use. Spill detection technology, to prevent the introduction into the sanitary sewer of a spill, such as gasoline, may be required. 